\title{
Un testimonio a múltiples voces. La rendición de los malbalaes según la Descripción Corográfica del Gran Chaco Gualamba, de Pedro Lozano
}

A testimony from multiple voices. The surrender of the malbalaes according to Description Corográfica of Gran Chaco Gualamba, by Pedro Lozano

\section{Beatriz Vitar}

\section{(2) OpenEdition}

\section{Journals}

\section{Edición electrónica}

URL: http://journals.openedition.org/corpusarchivos/656

DOI: 10.4000/corpusarchivos.656

ISSN: 1853-8037

Editor

Diego Escolar

\section{Referencia electrónica}

Beatriz Vitar, « Un testimonio a múltiples voces. La rendición de los malbalaes según la Descripción

Corográfica del Gran Chaco Gualamba, de Pedro Lozano », Corpus [En línea], Vol 4, No 1 | 2014,

Publicado el 30 junio 2014, consultado el 19 abril 2019. URL : http://journals.openedition.org/ corpusarchivos/656; DOI : 10.4000/corpusarchivos.656

Este documento fue generado automáticamente el 19 abril 2019. 


\title{
Un testimonio a múltiples voces. La rendición de los malbalaes según la Descripción Corográfica del Gran Chaco Gualamba, de Pedro Lozano
}

\author{
A testimony from multiple voices. The surrender of the malbalaes according to \\ Description Corográfica of Gran Chaco Gualamba, by Pedro Lozano
}

\author{
Beatriz Vitar
}

\section{NOTA DEL EDITOR}

Fecha de recepción del original: 10/03/2014

Fecha de aceptación para publicación: 28/04/2014

\section{Introducción}

Decía Roa Bastos, al referirse a las misiones guaraníes, que "el experimento jesuítico quedó como el libro escrito por un pueblo de iletrados que no conocían la escritura pero que conocían el lenguaje y la magia de los mitos, la ritualización social de la vida, la energía nutricia de la naturaleza"... A pesar de los estragos del tiempo y el despojo, ese "vasto libro en ruinas abandonado en medio de la jungla" (Roa Bastos, 1991, p. 12), nos habla del singular proceso de sincretismo cultural y social a lo largo de siglo y medio de vida misionera ${ }^{1}$. Las palabras del escritor paraguayo constituyen un buen punto de partida para reflexionar sobre aquellas fuentes, como la Descripción ${ }^{2}$ de Lozano, que si bien forman parte del monumental corpus de crónicas que construyeron la imagen de la alteridad "desde la posición privilegiada del lugar de enunciación asociado al poder imperial" (Lander, 2000, p. 16; Mignolo, 1995), son también en cierta manera obra de los 
pueblos nativos, cuyas acciones, palabras y gestos narrados por los otros, definen una agencia indígena en el marco de unas desiguales y conflictivas relaciones con el mundo colonial.

2 Por otro lado, frente a la metáfora con la que Roa Bastos retrataba el pasado jesuíticoguaraní, se alza la paradoja de la prolífica literatura que arrojó la experiencia ignaciana en ese y otros territorios misioneros en América. Al mismo tiempo, es dable recordar que, precisamente entre los guaraníes reducidos, fue un hecho destacable su incorporación a la cultura letrada a través de la escritura (Neumann, 2011), fenómeno con un claro impacto en el imaginario nativo, como planteara Gruzinski (1991) en el caso del México posterior a la conquista. De otros muchos pueblos con tradición oral no quedaron testimonios de su puño y letra, procedentes de los tiempos coloniales: sus voces quedaron secuestradas y convertidas en textos por quienes poseían el control de la escritura.

El encuentro e interacción de europeos e indígenas en las "zonas de contacto" y en el marco de unas "relaciones altamente asimétricas" (Pratt, 2011, p. 31), ha quedado registrado en una copiosa producción escrita de variado origen. En esa desigualdad de condiciones que signó el encuentro entre dos universos culturales opuestos, jugó un papel trascendental la posesión y control de la escritura por parte del sector hegemónico. La lengua y la escritura fueron inseparables de la obra imperial de España en América: desde sus inicios, las cartas, relaciones, crónicas y cualquier otra forma escrituraria fueron progresivamente dando nombre a un mundo inédito para los europeos, tanto en lo referido a sus pobladores como al orden geográfico-natural, quedando así de cada empresa de conquista y colonización su correlato documental ${ }^{3}$. La escritura se convertiría en una forma más de apropiación del universo indígena, de captura y dominio de los Otros, lo que adquiere un mayor dramatismo al producirse la toma de su palabra, (im)poniéndole el discurso dominante ${ }^{4}$.

4 Recorriendo la documentación archivística, diarios de viajes $\mathrm{u}$ otras fuentes coloniales, pero en especial las crónicas de miembros de la Compañía de Jesús (elaboradas por cronistas oficiales o responsables directos de la evangelización) es usual toparse con discursos indígenas, en forma de respuestas a los requerimientos de representantes del poder civil o militar, en los prolegómenos de los pactos o en diálogos sostenidos con los misioneros en el transcurso de la cotidianidad reduccional, en medio de los avatares de la asimilación a la "vida racional" o del proceso de conversión. Y más aún, se reproducen incluso diálogos entre indígenas (de un mismo o de diferentes grupos), como puede constatarse en el texto de Lozano aquí transcrito. Estos testimonios atrapados en la narrativa de la conquista militar y "espiritual", ¿podrían ser considerados como la versión más aproximada de lo que constituiría una fuente indígena "indirecta"? En cuanto a las crónicas jesuíticas, esas conversaciones entre misioneros y reducidos podrían ser definidas como una especie de monólogos dialogantes (valga el oxímoron para ejemplificar esos intercambios verbales referidos por los narradores), en los que, por lo general, los argumentos del orden dominante se erigen como expresión de legitimidad o criterios de autoridad, en oposición a los razonamientos o concepciones nativas. En esa dialéctica, las manifestaciones de estos últimos aparecen, las más de las veces, como manifestación del absurdo, de la irracionalidad o de la terquedad frente a la razón jesuítica. Ello se vuelve más nítido cuando los diálogos transcritos refieren al cruce de argumentos entre misioneros y reducidos con relación al bautismo o al mantenimiento de prácticas tradicionales, por citar unos ejemplos ${ }^{5}$. 
5 Ahora bien, la fuente aquí presentada, Descripción Corográfica del Gran Chaco Gualamba, del jesuita Pedro Lozano, no obstante constituir la versión unilateral de un episodio de guerra y negociaciones en la frontera tucumano-chaqueña, a la vez que informa sobre los mecanismos coloniales para someter a los grupos indígenas también lo hace con respecto a las decisiones, reacciones o estrategias de estos últimos para afrontar el asedio español. Dentro de la fuente captó mi interés la frase en primera persona atribuida al cacique "principal" de la etnia malbalá (Jonastete), que Lozano (1733, p. 370) introduce en su extenso relato sobre la conquista de este grupo en el siglo XVIII. El escueto mensaje en español estaba escrito en un papel que el líder malbalá enarbolaba en el extremo del dardo que entregó al gobernador del Tucumán, como señal de su rendición y oferta de paz. Detrás de lo que a primera vista puede parecer una manipulación de la voluntad y de la palabra indígena -el acto de sujeción expresado a través de la escritura en español y con la retórica al uso ${ }^{6}$ - subyacía una trama urdida al calor de las relaciones interétnicas y de los condicionamientos derivados de la presión colonial, como lo demuestran los sucesos producidos antes y después de las capitulaciones.

6 Los fragmentos seleccionados de la Descripción Corográfica del Gran Chaco Gualamba de Pedro Lozano ${ }^{7}$ ofrecen un completo relato sobre la primera entrada de Urízar al Chaco en $1710^{8} \mathrm{y}$ el desarrollo de las operaciones militares y negociaciones que precedieron al acuerdo de paz con los malbalaes, logrado a fines de agosto de aquel año ${ }^{9}$. De la mencionada crónica se han transcrito los Parágrafos LXVIII, LXIX, LXX y parte del LXXI, dentro del cual se encuentra la referencia a la leyenda que portaba el cacique en su arma en el día señalado para acordar la paz (Lozano, 1733, p. 370). El proceso previo a la "pacificación" arranca con el relato de los encuentros y escaramuzas del ejército del Tucumán con grupos mocovíes en las fronteras: apresamiento del cacique Coquiny y llegada de Apotquein al fuerte, principalmente ${ }^{10}$ (Parágrafos LXVIII, LXIX). En ellos encontramos algunas claves que explican los hechos posteriores al pacto hispanomalbalá, dado que la proclamada enemistad de estos con los mocovíes -a lo largo de las tratativas fronterizas- era parte de la estratagema para disimular la futura rebelión que ambos grupos orquestarían contra las fuerzas coloniales. Los Parágrafos siguientes (LXX y LXXI) contienen el desarrollo de las negociaciones con los líderes malbalaes hasta llegar a las capitulaciones con Jonastete, el cacique "principal" del grupo.

\section{La entrada al Chaco y la "pacificación" de los Malbalaes (1710)}

7 La política ofensiva contra los grupos chaqueños iniciada por el Tucumán a comienzos del siglo XVIII estuvo precedida por un estilo de guerra defensiva como respuesta a las acciones de mocovíes, abipones y tobas sobre los establecimientos fronterizos. Los fuertes y sobre todo las haciendas ganaderas instaladas en los confines orientales de la gobernación se habían convertido en una atractiva fuente de aprovisionamiento de vacas y caballos para los chaqueños. De la avanzada militar hacia este territorio dependía la seguridad y expansión del frente ganadero tucumano, con una producción clave para la economía regional en función de su inserción en el comercio altoperuano, sin descontar la perspectiva de capturar "piezas" sueltas para engrosar las débiles encomiendas que se mantenían en la provincia, reducidas a pocos indígenas (Vitar, 1997, p. 129-130). Las ciudades cuyas jurisdicciones lindaban con el Chaco eran las de Jujuy, Salta, Santiago del 
Estero y San Miguel, contando para su defensa con algunos fuertes, desde los cuales se realizaban algunas “correrías” o acciones defensivas (Vitar, 1997, p. 177).

En un cambio de rumbo, el gobernador del Tucumán, Esteban de Urízar y Arespacochaga puso en marcha un plan ofensivo con el fin de frenar el asedio a las colonias por parte de los grupos arriba nombrados, organizando una primera gran "entrada" al territorio indígena en 1710. La estrategia española para el afianzamiento de las fronteras orientales de la provincia tenía como objetivo último la sujeción de los pueblos chaqueños de "tierra adentro" (tobas, mocovíes, abipones), previa captación de los grupos situados en la periferia sudoccidental del Chaco, de "más suave índole", según la clasificación colonial. Entre estos últimos se hallaban los lules y vilelas que acabaron por acogerse al "amparo" español para huir de la presión mocoví, siendo congregados en las misiones fundadas en las fronteras del río Salado -territorio salteño- en los décadas de 1710 y 1720 . Vecinos a los mataguayos ${ }^{11}$, en los alrededores del río Grande o Bermejo en la jurisdicción de Salta, se hallaban unas "rancherías"12 malbalaes, a quienes el jesuita Joaquín Camaño describió como una "parcialidad" de los vilelas (en Furlong, 1939, p. 40), aunque posteriormente señalaría su dispersión y mezcla con otros grupos, tales como los mocoví y mataguayos ${ }^{13}$. Los malbalaes (pescadores-cazadores, criadores de ovejas y pequeños cultivadores ${ }^{14}$ ) tuvieron su primitivo hábitat en el Bermejo medio, debiendo abandonar estas tierras ante el acoso mocoví (Kersten 1968, pp. 86-87) y replegarse hacia zonas más próximas a la jurisdicción de Salta, circunstancia que explica su decisión de pactar con los españoles durante la campaña de 1710. Por su parte, Lozano ratifica en la Descripción las conflictivas relaciones que mantenían entonces los malbalaes con los mocovíes y otros pueblos chaqueños: "Profesan [los malbalaes] declarada enemistad con todas las naciones mencionadas, como Mocovíes, Tobas, etc. y sólo son amigos de los Chunupíes y Vilelas" (Lozano, 1733, p. 84).

9 La rendición de los malbalaes se negoció durante la citada entrada de Urízar al Chaco tras una acción victoriosa de uno de los tercios del ejército del Tucumán en las fronteras del río Grande o Bermejo, donde atacaron los asentamientos de la "principal parcialidad" de aquella "nación" (Lozano, 1733, p. 367). A este suceso siguieron la toma de prisioneros y las negociaciones con la jefatura malbalá, que culminaron con la formalización del acuerdo de paz en un acto solemne, con asistencia del gobernador. Una vez hechas las capitulaciones (Lozano, 1733, pp. 370-375), centenares de malbalaes ${ }^{15}$ fueron trasladados a las fronteras de Salta, siendo alojados en el fuerte de Valbuena, cerca de la antigua ciudad de Esteco. Este primer avance del plan ofensivo no se tradujo en un éxito duradero para las fuerzas coloniales, ya que poco después de ser reducidos los malbalaes se rebelaron; una vez sofocado el movimiento y como castigo ejemplar, fueron trasladados a Quilmes jurisdicción de Buenos Aires- y otorgados en encomienda a José de Arregui, maestre de campo de Salta. Varios capítulos más adelante, al tratar de las misiones lules, Lozano alude brevemente a la sublevación y posterior destierro de los malbalaes a Buenos Aires, sobre lo que aportan mayores detalles los informes oficiales de la campaña (Vitar, 1997, pp. 189-190). En uno de ellos, el gobernador Urízar comunicó no sólo el levantamiento en Valbuena, sino una segunda reacción de los malbalaes, en concreto a las puertas de la ciudad de Santiago, mientras iban camino de Buenos Aires; en esta ocasión habían cargado contra sus centinelas, no haciéndose esperar la represión española: algunos malbalaes escaparon y otros afrontaron la lucha, "resistiéndose hasta morir, de suerte que de los guerreros, ninguno quedó vivo"; finalmente, los que se "recogieron "a fuerza de notable diligencia" fueron 170 , entre "mujeres y muchachos" ${ }^{16}$. Nada especificaba 
Urízar en su informe acerca del destino del intérprete, salvo el haber confesado este la alianza conspirativa con los "mocovíes, tobas y demás naciones [...], sus antiguos amigos y [que] despreciaban la amistad del español"17.

\section{Relato jesuítico y escritura indígena en las fronteras}

\subsection{Sobre fuentes y autoría(s)}

10 El contexto de producción de la fuente induce a plantear algunas consideraciones desde la perspectiva del autor y los objetivos de su obra. El jesuita Pedro Lozano escribió la Descripción en su condición de "cronista de la provincia del Tucumán", tal como reza en la portada de la edición original de la obra. Los hechos acontecidos (la secuencia histórica de los mismos) y la forma y fines en que se elabora su relato han sido objeto de una ya consistente producción historiográfica, a partir del análisis de Paul Ricoeur en Tiempo y narración (1958). A propósito de la narrativa surgida durante los procesos de formación nacional en América Latina, Colom González, citando a aquel autor, señalaba que la narración ficticia o histórica “(...) alcanza su plena capacidad de significación cuando se convierte en condición de la experiencia temporal. (...) El tiempo narrado se representa en la trama de la historia diacrónicamente, como acontecer, permitiendo que ésta se dote de una finalidad" (Colom González, 2003, pp. 329-330. El resaltado me pertenece).

11 La crónica de Lozano apuntaría así a la justificación de los procedimientos y estrategias coloniales en la guerra y diplomacia fronteriza en aras de someter a los pueblos chaqueños. En tal sentido debe tenerse en cuenta, además, el hecho de que el cronista informa de los sucesos fronterizos basándose en unas "relaciones" (con seguridad, informes gubernamentales sobre la campaña al Chaco de 1710), a las que cita en varios pasajes del texto aunque sin aportar otras referencias. En el marco de ese fin legitimador se encuadraría incluso el escrito presentado por el cacique "principal" Jonastete en nombre de su grupo (y en los términos acostumbrados por los colonizadores), lo que a primera vista podría calificarse como un testimonio indígena inducido por los españoles a través del intérprete o bien sugerido por este último. Aunque el relato no ofrece indicios al respecto, es posible conjeturar que fue Ays/Antonio el lenguaraz quien redactó el texto referido a la rendición, poniéndolo luego por escrito. Los acontecimientos ocurridos después, las dos rebeliones malbalaes en alianza con los mocovíes y la confesión del mismo intérprete, según consta en la citada carta del gobernador Urízar al rey ${ }^{18}$, podrían también llevarnos a considerar dicho testimonio como obra colectiva, es decir, fruto de un plan premeditado del intérprete y los líderes malbalaes, sin descontar la intervención mocoví.

12 En suma, atendiendo a la aportación de contenidos referidos a las prácticas nativas y a sus intercambios con el mundo colonial, la Descripción de Lozano responde al tipo de una "literatura de fronteras" y, como tal, constituye un producto narrativo en el que están presentes los agentes que interactúan en ese contexto. Los espacios fronterizos resultan, por ende, sumamente propicios en cuanto a la generación de un tipo de documentos que, como sostiene Wilde, más que adscribirse a una autoría concreta, son el resultado de intercambios entre dos culturas diferentes (2013, p. 1), encuentros de los que unos y otros no salieron indemnes. En este aspecto, la obra de Lozano recoge múltiples voces: la versión oficial sobre la actuación del frente pionero, volcada en esas "relaciones" usadas por el cronista como fuente primaria para su narración que, por lo demás, constituye un 
panegírico de la actuación militar de Urízar ${ }^{19}$. Todo ello, sin desdeñar el recurso a la memoria oral, es decir, a los testimonios directos o indirectos provenientes tanto de indígenas como de miembros del ejército o misioneros, referidos a las interacciones fronterizas. En cuanto al mundo nativo, es de destacar la referencia de Lozano al sitio donde habitaban los mocovíes según la información del P. Antonio Machoni (años después a cargo de una de las reducciones del Salado en Salta), quien la había obtenido a su vez "de cierto Indio anciano y principal de Nación Toquistiné"20 (Lozano, 1733, p. 349). El siguiente fragmento ilustra acerca de los recursos testimoniales que afloran en el relato de Lozano:

Volvióse ahora a tocar el punto [del sitio que solicitaban los malbalaes para su reducción] con el Padre de Antonio [el intérprete], y creen muchos que desde luego se lo ofreció el Maestre de Campo Alurralde, aunque las relaciones sólo dicen que se le respondió que viniese su Cacique, con quien hablarían y pasarían a ver al Apu grande (que así llaman estos bárbaros al Gobernador) para que lo determinase, que suspenderían las armas contra ellos, alojándose ocho o diez leguas de nuestro Real Río Grande abajo, durante la campaña (Lozano, 1733, p. 362. El resaltado me pertenece).

\subsection{Tratativas y acuerdo de paz en las fronteras: actores, tradiciones y apropiaciones culturales}

13 Para situarse en el escenario de los hechos, resulta pertinente resaltar el modo en que Lozano define dos espacios nítidamente contrastados, el de la "civilización" y el de la "barbarie", simbolizados, respectivamente, por el llano (donde los españoles se movían con soltura, desplegando sus fuerzas para atemorizar a los indígenas, terreno que presenta a la vez como metáfora de verdad, rectitud y claridad de intenciones) y por la "espesura" (el bosque, reducto de unos "bárbaros" proclives al engaño y la traición), ámbito fuera del control colonial $\mathrm{y}$, por cierto, con resonancias demoníacas en el imaginario europeo.

14 En el marco de los intercambios hispano-indígenas en las fronteras, asistimos también a fenómenos de transculturación en uno y en otro sentido. Sin duda, se trata de un hecho inédito el uso de señales de humo por parte de los españoles para responder a las que harían el padre ("capitán" Taclete Illis) y el hermano de Ays/Antonio el lenguaraz, una vez retornados a sus rancherías con la promesa de transmitir las propuestas coloniales de paz. Al respecto, relata Lozano:

Dieron algún vestido al hermano de Antonio, y Padre e hijo se volvieron muy contentos, diciendo el viejo tuviesen por cierto vendrían los maridos de las prisioneras, y por señas harían humos, a que rogaba les respondiesen con otros. Los Españoles trataron de caminar, porque su bastimento era ya poco; y estándose alojando, vieron la seña del humo, a que respondieron puntuales (...) (Lozano, 1733, p. 363. El resaltado me pertenece).

15 Así también, el momento de las capitulaciones estuvo acompañado por la habitual confirmación del cacique en su rango de "principal", el otorgamiento del grado de Sargento Mayor al intérprete Ays/Antonio en recompensa por sus oficios y de insignias (bastones) a ambos, sin faltar ese "abrazo" del gobernador a Jonastete (Lozano, 1733, pp. 371-372), un gesto que probablemente habría provocado perplejidad entre los indígenas.

16 Por parte de los malbalaes, el recurso a la escritura y el hecho de presentar las armas en señal de rendición y oferta de paz (sobre lo que volveré más adelante), pone a la vez de manifiesto la apropiación de usos y modalidades del mundo conquistador. En el terreno 
de la incorporación de bienes materiales provenientes de las colonias, como es sabido, la adopción de caballos por los pueblos chaqueños había significado la disponibilidad de un ventajoso instrumento bélico, al igual que lo era para los españoles; ambos contrincantes procuraron su conservación y/o captura, según el caso, convirtiéndose el ganado caballar en objeto de una auténtica guerra de recursos.

Sumándose a las prácticas transculturales, una peculiaridad de las zonas de contacto (Pratt, 2011, p. 32), en el episodio de historia fronteriza narrado en la fuente se perfila un contexto multilingüístico ${ }^{21}$ en el que se mezclan diálogos en las lenguas española, quechua, mocoví y malbalá. Los malbalaes usaron el quechua en el caso de términos puntuales como $\mathrm{Apu}^{22}$ (Lozano, 1733, p. 362) y también en la comunicación con los mocovíes, como refiere Lozano al comentar el diálogo sostenido por Ays/Antonio con Coquiny, el prisionero mocoví en el campamento español (Lozano, 1733, p. 364).

En el plano de la información sobre la cultura indígena, la contribución de Lozano reviste gran importancia. A medida que este cronista va dando cuenta de los sucesos fronterizos (dicho sucintamente: ataque contra las rancherías malbalaes en las cercanías del río Grande, victoria española y toma de prisioneros, envío de una anciana mensajera y sucesivas presentaciones de "capitanes", caciques menores y otros miembros del grupo en el campamento español, incluyendo a los actores mocovíes), hasta llegar al acuerdo con el cacique "principal" Jonastete, la narración prodiga detalles sobre la vida indígena (jefatura, hábitos guerreros, atuendos, costumbres de duelo, entre otros), lo que la convierte en una valiosa fuente etnográfica, sin obviar el colorido con el que se aligera la densa prosa que recoge los movimientos del ejército colonial en las fronteras o la retórica providencialista cristiana.

19 En lo que concierne a los protagonistas que de un modo $u$ otro participaron en las tratativas previas al acuerdo de paz y en este mismo, uno de los personajes clave fue, de principio a fin, el lenguaraz Ays, rebautizado como Antonio ${ }^{23}$ quien, además de intervenir en las negociaciones con los malbalaes, medió entre las fuerzas militares y algunos líderes mocovíes en las fronteras. El intérprete malbalá es presentado por Lozano (sin duda siguiendo la versión "oficial" de la campaña de 1710 remitida por Urízar a la corona, en la que consta que se trataba de un "caudillo" ${ }^{24}$ ) nada más comenzar el relato sobre el inicio de las operaciones, con las que se pretendía

(...) sin estrépito de armas sacar de su barbarismo a la Nación Malbalá, mediante la industria de un Indio de la misma Nación llamado Antonio, a quien Don Antonio de Alurralde, Maestre de Campo de dicho Tercio, había apresado el año antecedente de 1709, en la Frontera de Esteco, siendo Castellano de aquel Real Presidio, y a la sazón le llevaba consigo (Lozano, 1733, p. 347. El resaltado me pertenece).

20 La captación de intérpretes, fundamental en la guerra y la "diplomacia" (así como en muchas otras circunstancias de la conquista militar y "espiritual"), había sido además expresamente estipulada en la Instrucción dada por Urízar al Maestre de Campo del Tercio de Salta antes de iniciar la campaña de 1710, con miras a la sujeción de los grupos chaqueños considerados enemigos "capitales" de las colonias (tobas, aguilotes, mocovíes); así, en el caso de “(...) que haga yo la guerra a estos Bárbaros”, prevenía Urízar a su subalterno, (...) si le pareciere conveniente, reservará la vida a algunos de los Grandules, para que le sirva de lengua y guíe a las Rancherías y parajes de su retirada, solicitando en todo caso quitar el [al] enemigo los caballos por lo que les importa" (Lozano, 1733, p. 344). actuaciones coadyuvaron a las capitulaciones pactadas con Jonasteté. La fuente presenta 
todo un protocolo de comparecencias y promesas de miembros de la jefatura malbalá en sus distintos niveles jerárquicos; en ocasiones, acompañados de algunos parientes, lo que progresivamente va revelando la red de parentesco que los unía. En la sucesiva presentación de caciques "menores" y "capitanes" de los malbalaes en el campamento español, tras el envío inicial de la "india mensajera" (apresada durante la operación militar contra las rancherías malbalaes), se transluce la intención indígena de mostrar su aparato de poder y de alimentar las expectativas coloniales retrasando la aparición del cacique "principal" Jonastete. Desde el lado colonial, esta progresiva incorporación de actores a las tratativas fronterizas -que culminaría con la entrada final en escena de Jonastete- era percibida como señal de que "iba tomando cuerpo el negocio" (Lozano, 1733, p. 363).

La intervención femenina en ese proceso no fue nada desdeñable, si se considera que varias mujeres malbalaes realizaban espionaje en las fronteras mientras los españoles instalaban su Real en las cercanías del Río Grande (Lozano, 1733, p. 361). En lo que respecta al proceso de paz fue crucial la intermediación de una "india muy anciana", escogida entre los prisioneros malbalaes como mensajera para transmitir a su grupo la invitación española a reducirse (Lozano, 1733, p. 361). Por otro lado y aunque no con una presencia directa, la hermana del intérprete y mujer, a su vez, del cacique Jonastete, fue parte decisiva en la estrategia de retrasar el encuentro de su esposo con las fuerzas españolas, de cara a fijar el sitio donde se establecería la futura reducción; así, en una segunda visita al campamento colonial, el capitán Taclete Illis (padre de Antonio el lenguaraz ${ }^{25}$ ) justificó la tardanza de Jonastete en presentarse, argumentando que su mujer "tenía todavía sus desconfianzas, y por no disgustarla le había rogado [el cacique al padre de Antonio] volviese otra vez al Real de los Españoles, y según se fuese, se determinaría a hablarles" (p. 363).

Siguiendo la secuencia de hechos que ofrece la Descripción, con posterioridad acudieron al campamento español otros tres jefes malbalaes: el "capitán" Jonays (padre de una de las prisioneras), quien "presentó" su dardo al maestre de campo Alurralde como "señal de paz y amistad" (Lozano, 1733, pp. 363-364), el Cacique Jonapayn, "a quien trajeron los suyos para tratar la paz", y el "capitán" Oonays, "muy nombrado entre todos los de su Nación", acompañados del pariente de uno de los jefes (p. 366). La visita de todos ellos antecede a la aparición de Jonastete para celebrar las capitulaciones, previo a las cuales había comparecido una primera vez para ofrecer verbalmente su rendición y propósito de reducirse con su grupo ${ }^{26}$.

Finalmente, según el relato de Lozano, la rendición y oferta de paz de los malbalaes se formalizó con la presentación del cacique Jonasteté junto a otros "caciques menores" y "capitanes" de su "nación"; dentro de la comitiva se hallaba también "la India que fue por mensajera, a quien llamaban la Conquistadora; porque con sus buenas razones inclinó a su Nación a la paz" (Lozano, 1733, p. 369). Contrario a lo que ocurre con los líderes, a quienes alude por su nombre, en el caso de esta mujer (una anciana malbaláa ${ }^{27}$ ), que abrió el proceso de negociación con su oficio de "mensajera", Lozano sólo se refiere a ella con el alias de "la Conquistadora". Nada dice tampoco acerca de su rango o parentesco con otros protagonistas de las negociaciones de paz, salvo la referencia a sus oficios en calidad de "mensajera"; al respecto es oportuno recordar que el citado cronista destaca en otra de sus obras la función de "pregoneras" que cumplían las ancianas entre otros grupos del Chaco (en Vitar, 2004, pp. 57-58). 
25 En el acto de rendición, Jonastete entregó al gobernador Urízar el papel que había colocado en el extremo de su arma para ratificar su decisión y voluntad de amistad con los españoles. El papel contenía la siguiente leyenda: Jonastete, Cazique de la belicosa Nación Malbala, vengo rendido a daros la paz en nombre de toda ella.

En la fuente esta frase figura en cursiva, lo que deja entrever la intención de resaltar dentro de la narración la consecución de un primer logro de la expedición colonial a las fronteras en 1710, como lo fue el sometimiento de los malbalaes. El gesto de entregar su arma ("un dardo negro muy lucido"28) al gobernador del Tucumán, estaba cargado también de un valor añadido, dada que el uso de este tipo de arma era atributo propio de las jerarquías de mando entre los malbalaes, según el mismo Lozano subrayaba al describir las costumbres de este grupo: "[Sus] armas son las que usan las otras Naciones, excepto que el dardo no se permite promiscuamente a todos, sino a solos los Caciques y Capitanes, y así viene a ser esta su insignia y distintivo" (Lozano, 1733, p. 84).

Por otra parte, la presentación y entrega de sus respectivos dardos al gobernador del Tucumán, hecha por el "capitán” Jonays (durante la fase de negociación) y por el cacique Jonastete (en el momento de "asentar" la paz), da a entender que los líderes conocían de antemano (es probable que por boca del lenguaraz) una de las condiciones impuestas por los españoles para celebrar cualquier acuerdo con los indígenas, como la de presentarse sin armas: precisamente, en las Instrucciones dadas por Urízar al Maestre de Campo de Salta figuraba el que "si alguna Nación o parcialidad le ofreciere la paz, no la admitirá por mal segura [sic], ni a ellos en su Real sino desarmados” (Lozano, 1733, p. 344).

La entrega a Urízar del arma cacical con el papel ensartado en su extremo, daría lugar al momento álgido del episodio narrado por Lozano, y no sólo, claro está, por el hecho de quedar refrendada por escrito la rendición de los malbalaes. En primer lugar, en este episodio de "diplomacia" fronteriza, la recepción por parte del gobernador de un texto de autoría indígena en tales términos, confería al suceso una fuerza legitimadora: los indígenas asumían así una historicidad de la que carecían por la ausencia de escritura. Por otra parte, llevando la mirada hacia el comportamiento nativo, puede definirse como el gesto de apropiación de una herramienta de la cultura dominante, algo similar a lo que Wilde (2009) destacaba en el caso de los guaraníes reducidos al "hacer suyo un discurso religioso marcado por la alteridad" (p. 113). En este sentido, la figura del lenguaraz Ays/ Antonio, quien "había vivido en Buenos Aires, y estaba muy pagado de las conveniencias de aquel País", vuelve a ocupar un lugar central, ya que es muy posible que tuviese conciencia de la significación y funcionalidad de la escritura ${ }^{29}$. Las palabras del cacique Jonastete que Lozano nos "da" a leer no eran sólo expresión de una decisión comunitaria a través de la jefatura, sino que conllevaba también el auto reconocimiento de la "belicosidad" malbalá, utilizando la propia jerga de los conquistadores. El abandono de las hostilidades se completaba así con la acción verbal mediante la "entrega" de la palabra y del arma del cacique al gobernador, un acto de puro sincretismo en el que se conjugaban un símbolo occidental (la lengua española en la que iba escrita la oferta de paz de los malbalaes) y un objeto indígena, el dardo del líder principal.

Una de las preguntas que se podrían formular en torno al testimonio del cacique es, en primer lugar, qué niveles de autoría podrían establecerse, ya que de la narración se deduce que la oferta de paz y el posterior acuerdo fue el resultado de la actuación de varios agentes. Así, la escueta y a la vez significativa frase de Jonastete que aparece en el texto de Lozano no sólo plasmaba una decisión de la jefatura (cacique principal y caciques menores) sino que era a la vez el producto de una cadena de intervenciones, que se 
coronaba con la re-escritura del acontecimiento por parte del cronista. ¿Fue el lenguaraz Antonio/Ays, en calidad de portavoz, el autor de la frase, en el caso de haber adquirido la herramienta de la escritura? Como he señalado antes, el intérprete era hijo de Taclete Illis, uno de los "capitanes" que formaron parte de la comitiva que se presentó ante el gobernador; y, en este punto, es necesario remontarse al inicio de las negociaciones, con la aparición del citado Taclete Illis en el Real español en la frontera ${ }^{30}$, ocasión en que padre e hijo "hablaron muy despacio" (Lozano, 1733, p. 362), para inclinarnos a pensar que fue entonces cuando el plan malbalá comenzó a ponerse en marcha.

A ese escrito que portaba el cacique, ¿podría definírsele como una fuente indígena más o menos "directa", si se compara con los ejemplos anteriores, es decir, las supuestas manifestaciones verbales indígenas reproducidas en los textos coloniales, a las que aludía al comienzo de estas notas? Como apunta Wilde (2013, p. 1) al señalar el carácter de "corpus ambiguo" que conforman cierto tipo de fuentes, en el caso del testimonio de Jonastete (dentro de la crónica de Lozano), el contexto de elaboración del mismo nos remite, por un lado, al modus operandi español a través de las instrucciones dadas al intérprete (previamente aleccionado, tras haber sido apresado en las fronteras con anterioridad a la entrada al Chaco de 1710), mientras que por otro revela la presencia de un sujeto colectivo o, dicho de otro modo, el fruto de una acción coordinada entre el lenguaraz malbalá y otros líderes de su grupo para dar la respuesta esperada por los españoles, comenzando por las "instrucciones" dadas a la "india mensajera" al inicio de todo el proceso (Lozano, 1733, p. 362). o bien, ¿podría atribuírsele la autoría al maestre de campo Alurralde, al mando del tercio? Este militar fue, al parecer, también artífice de la puesta en escena para el gobernador, al que había convocado con urgencia para solemnizar el acuerdo con los malbales. Por otra parte, la forma en que Jonastete materializó su oferta de paz no se inscribe en una tradición indígena, lo cual añade un componente de interés al suceso. La decisión de concretar la rendición a través de la escritura, ¿era tal vez una estrategia indígena para persuadir a los españoles de que obraban con sinceridad, apelando a la escritura, una herramienta propia de los conquistadores, para dar mayor contundencia al acto? ¿Acaso no era suficiente la transmisión oral por parte del intérprete? Los sucesos desencadenados posteriormente, es decir, los dos levantamientos que protagonizaron los malbalaes aliados con los mocovíes tras ser reducidos en Balbuena, permiten corroborar que se trataba de una estratagema de los primeros para salir del paso, escapando a una previsible acción mocoví contra ellos, tal como se lo dieron a entender a las fuerzas coloniales.

31 Atendiendo a todas esas circunstancias, más allá de una autoría individual o colectiva, española o indígena, la fuente en sí, de un modo general, y el escrito del cacique en particular, constituyen el corolario de un complejo proceso de interrelaciones entabladas por los actores que confluyeron en las fronteras: los malbalaes, los mocovíes y el frente pionero del Tucumán.

\section{Consideraciones finales}

En estas notas he expuesto algunas cuestiones de interés sobre las que es preciso seguir ahondando, tanto en lo que se refiere a las condiciones de producción del propio relato y a su función legitimadora de la política ofensiva contra el Chaco en los inicios del siglo XVIII, como en lo inherente a la agencia indígena en un espacio de fronteras, que desmonta las clásicas interpretaciones sobre una avasalladora avanzada española sobre el 
mundo nativo. Sin desconocer los efectos de la presión colonial sobre el territorio chaqueño, que albergaba un variado conjunto étnico cuyas relaciones se regían por un particular mecanismo de alianzas, su resistencia al frente colonizador se canalizó a través de una estrategia bien planificada. En el caso aquí comentado, en su urdimbre jugaron un papel clave el lenguaraz y la jefatura, que flexibilizó sus mecanismos tradicionales de actuación acomodándose a las demandas españolas, sacando partido de ello.

En otro orden de cosas, unas someras reflexiones en torno a la definición de lo que constituye propiamente una fuente indígena, permiten adelantar, considerando el caso aquí presentado, que nos hallamos ante un contexto complejo de elaboración del relato, y más aún de esa oferta de paz por escrito que Jonastete presentó al gobernador. En tanto la fuente aquí presentada se enmarca en un espacio de fronteras, signado por la intensidad de los encuentros e intercambios entre las fuerzas coloniales y grupos indígenas, encierra una particular riqueza en cuanto a información relativa a ambos universos culturales, enfrentados en ese contexto y en una coyuntura singular.

En el relato de Lozano sobre las distintas fases del episodio fronterizo se entrecruzan las voces del español y las de los idiomas nativos, se enredan las densas lenguas de humo propias de la comunicación entre "gentiles" y la humareda de las fogatas del Real español, lucen los dardos de los caciques y se oyen salvas de fusiles alternándose con la "armonía" de los malbalaes, dando golpecitos en sus bocas en "señal de "alegría y de paz"... Así de pródiga es esta historia de fronteras y también su narración.

\section{Fuente: Pedro Lozano, Descripción Corográfica del Gran Chaco Gualamba.}

\section{\&. LXVIII}

\section{ENTRADA DEL EJÉRCITO ESPAÑOL AL Chaco, y sus operaciones hasta llegar al Río Grande ${ }^{32}$}

-Pág. 34733 - Los tercios de Salta y Jujuy entraron cada uno al Chaco por sus fronteras, encaminándose hasta el Río Grande, como mandaba el Gobernador y se había resuelto en las Juntas de Guerra. Al de Tucumán se le ordenó que por la frontera de Esteco ${ }^{34}$ marchase vía recta al mismo Río y construyese en sus márgenes un Fuerte, donde dejase los bastimentos, y corriese Río abajo, para probar si podían sin estrépito de armas sacar de su barbarismo a la Nación Malbalá, mediante la industria de un Indio de la misma Nación llamado Antonio, a quien Don Antonio de Alurralde, Maestre de Canpo de dicho Tercio, había apresado el año antecedente de 1709, en la Frontera de Esteco, siendo Castellano de aquel Real Presidio, y a la sazón le llevaba consigo. A dicho tercio mandó el Gobernador siguiese el del Valle de Catamarca convoyando el bagaje y bastimentos necesarios para la manutención del ejército el tiempo que se detuviese en lo interior del Chaco, y su Señoría se quedó en el Presidio disponiendo el informe que hacía al Rey nuestro Señor de aquella Campaña, disponiendo seguir la marcha escoltado de los Cabos reformados. Cinco días después, que fue a diez de Julio, salió de Esteco el Gobernador, y cuando imaginaba se habrían adelantado espacio considerable los que le precedían, los alcanzó en el paraje de Balbuena, donde habían parado y hecho un Fuerte solas diez y ocho leguas distante del Fuerte del Rosario de Esteco: varias fueron las razones que motivaron esta demora: fueron la primera decir que dos partidas avanzadas a reconocer el terreno hasta el Río del Valle, 
distante catorce leguas de Balbuena, habían traído noticia de que estaban sin pastos todas las Campañas, por haberse quemado, con [348] que el exponerse a pasar adelante era exponerse a manifiesto riesgo de que pereciesen hombres y animales. La segunda, que era imposible conducir en carretas, como se conducía el bagaje y bastimentos, porque los muchos y profundos zanjones que atravesaban todo el camino, negaban totalmente el paso. No parecieron estas razones subsistentes [sic] al magnánimo Gobernador, antes concibiéndolas por hijas del miedo: habló a todos con grande resolución, y les mandó proseguir la marcha. Protestando seriamente, que a quien intentase retroceder cobarde, le haría luego cortar la cabeza, para perpetuo escarmiento. Diéronle tercera razón, que fue verdadera, y esta había sido que al llegar a aquel sitio de Balbuena, vieron salir de un monte redondo un Indio infiel, a quien por más que siguieron se les escapó: porque pasando con gran ligereza el Río Valbuena, se internó en el espeso bosque de la otra banda. Oída esta razón por el Gobernador, y recelándose como prudente general no tuviese alojada en aquel bosque alguna partida de enemigos, que dejando pasar todo el Ejército Español a lo más interior del Chaco intentase pasar a arruinar las Ciudades inmediatas de la Frontera, como sucedió antiguamente con la Ciudad de la Concepción del Río Bermejo, mandó al Maestre de Campo don Esteban de Nieva y Castilla que, entresacando de su Tercio 150 Soldados los más escogidos, pasase con ellos a registrar diligentemente aquel terreno. Ejecutólo así, y andando en esta diligencia llegó al Real del Gobernador un trozo de enemigos que, espantando la caballada que pasteaban los Indios Cristianos auxiliares, se la llevaban a su salvo, por haber estado emboscados en la selva próxima; pero no lograron el lance; porque luego que tuvo el Gobernador la noticia, ordenó fuese en su alcance un Cabo de los Reformados, Don Jerónimo de Peñalosa, valeroso Soldado, que había militado en las guerras de Cataluña. A corto trecho alcanzó a los enemigos, que al ver a los Españoles huyeron desamparando la Caballería, que restituyó Peñalosa enteramente a los Indios amigos, cuya era. Vuelto el Maestre de Campo Nieva, dio cuenta al Gobernador de su expedición, diciendo como en todo aquel terreno y bosques cercanos, no había encontrado Infiel alguno; pero sí una grande -349- Ranchería vacía, que se reconoció habían poco antes abandonado; pues halló aún ardiendo los fogones y en ellos las ollas llenas de comida que estaban aderezando, por lo cual, y por los muchos rastros se persuadía no estar distante algún trozo grande de Infieles con numerosa chusma de mujeres y niños. No se engañó con su discurso: pues como el año siguiente supo el Padre Antonio Machón, Misionero de la Reducción de los Lules, por relación de cierto Indio anciano y principal de Nación Toquistiné, tenía su habitación en aquellos bosques, que confinaban con las tierras y Rancherías de las Naciones Isistinés, Toquistinés, Oristinés y Tecus, todas pacíficas y de a pie, un famoso Capitán de Nación Mocoví llamado Notivirí, con una parcialidad numerosa de los suyos, quienes frecuentemente robaban y mataban a los pasajeros de en los caminos de Salta y Jujuy, siendo tal de su osadía, que tres cuartos de legua de la Ciudad de Salta, en las estancias y Caserías se atrevió, por Octubre del año de 1709, a degollar varias persona, y en alguna mayor distancia degolló doce días después ochenta hombres, mujeres y niños, lo que les dio aliento para asaltar la misma Ciudad, donde sólo quitó la vida a un mudo, por haber sido sentido y repelido de los vecinos. Viendo pues Notivirí el gran poder con que entraban ahora los Españoles al Chaco, abandonó con todos los suyos su Ranchería, y por haber reconocido cuánto lo podía ofender un Fuerte, que en el sitio de Balbuena mandó construir el Gobernador, como después diré, trató de retirarse de aquella comarca con sus vasallos y gran número de caballos que había robado en las haciendas de los Españoles y persuadió la misma transmigración a toda la Nación de los Aguilotes, de manera que 
todos, aquel año de 1710 se trasladaron muchas leguas de distancia al País de los Abipones Infieles Fronterizos a la Ciudad de Santa Fe de la Vera Cruz en la Provincia del Río de la Plata, a la cual tienen casi arruinada con las continuas hostilidades y muertes que han ejecutado Abipones, Mocovíes y Aguilotes en ella y su jurisdicción desde que llegó a aquel paraje el famoso Notivirí, que pagó tantos delitos muriendo obstinado en su infidelidad.

Siendo de estas calidades Notivirí, ya se echa de ver fue -350- no pequeña victoria haberle desalojado de las Fronteras de la Provincia de Tucumán, y para asegurarlas del todo, mandó el Gobernador construir en aquel paraje de Balbuena una fortaleza con la advocación del Proto Mártir San Esteban, guarnecida de competente número de Soldados del Tercio de Catamarca, dejando por Castellano de ella al Sargento mayor Don Nicolás de Vega, y por su Capellán durante la campaña al Padre Joaquín de Yegros, que lo era del Tercio deshecho de Santiago, que atendió con todo fervor a los ministerios de nuestra profesión en beneficio de aquella guarnición. Ejecutado este orden, mandó el Gobernador proseguir a fines de Julio la marcha al Río del Valle de los Castellanos, distante catorce leguas de Balbuena, y no es de pasar en silencio el método Cristiano que en todas las marchas observó en toda la Campaña el piadoso Gobernador; porque todos los días antes de empezar la jornada, daba tiempo competente para que el Padre Machoni, Superior de la Misión Castrense y su Capellán, celebrase el Santo Sacrificio de la Misa, a que asistía Su Señoría con singular devoción, y todos los Reformados y comitiva del Capitán General: de parte de tarde, después de meter la guardia, se rezaba con igual piedad el Rosario de la Santísima Virgen, delante de la Sagrada Imagen de la advocación del Rosario, a quien, imitando al Gloriosísimo Rey de España San Fernando, encomendaba afectuosamente el religioso Gobernador los buenos sucesos de la guerra; concluíase el Rosario con las Letanías Lauretanas y algunas oraciones vocales en sufragio a las Ánimas del Purgatorio. El mismo método observaban los Padres Capellanes de los demás Tercios. En el Río del Valle se detuvo el Gobernador hasta 20 de Agosto, ocupado en concluir el informe para el Rey Nuestro Señor, que en medio de tantos embarazos no se descuidaba en punto de lo que era tan de su obligación, por las órdenes de Su Majestad. En el ínterin, el Maestre de Campo Nieva corría los contornos de aquel sitio, en que andaban los Infieles divididos por familias, para huir con mayor facilidad de las armas Españolas; pero era vano su desvelo, porque se mataron muchos Indios guerreros, y se apresaron otros de avanzada edad -351y párvulos de ambos sexos. Estos, catequizados e instruidos los que eran capaces por el Padre Antonio Machoni, fueron por él mismo lavados en las saludables aguas del Santo Bautismo, y se daban en premio para que sirviesen en tierras de Cristianos sacados de aquel barbarismo a los mismos que los apresaban. Los despojos que los Españoles quitaron a estos Bárbaros eran solo muchos cascos de cabezas de Cristianos de los que habían degollado en las invasiones antecedentes y guardaban colgadas en los ranchos, para servirse de ellas en las borracheras con que celebran sus triunfos, o las colgaban de los árboles para testimonio de su valentía: a todas les daban los españoles sepultura.

Son imponderables el hambre, desdichas y miserias que en este tiempo padecían los bárbaros, por no querer hacer las paces con el Español: llenos de horror, confusión, terror y espanto, flacos y macilentos, no sabían a donde huir ni donde esconderse, pues como ellos mismos contestaron todo el Chaco estaba lleno de Españoles, de manera que ni aún para buscar el corporal alimento se atrevían a salir de sus madrigueras, los bosques más espesos e impenetrables breñas. Y faltándoles toda seguridad para poderse avisar unos a otros del manifiesto peligro que corrían sus vidas, se comunicaban y hablaban como hijos de la confusión gentilicia, con lenguas de humo, que es la seña con que de lejos se 
entienden y hablan. Porque todos los días, desde la una o dos de la tarde, se divisaban en toda aquella campaña del Chaco columnas de espeso humo, que saliendo de entre los bosques y selvas, subían derechas hasta las nubes. Fórmanse estas columnas de humo de unas piras que hacen de muchos trozos de leña bien gruesa o seca a las cuales después de pegarles fuego y arder bien, cubren con grandes haces de hierbas verdes: con que en lugar de levantar llama, todo el ardor se resuelve en humo, y como por la espesura impenetrable de aquellos bosques no puede correr el viento, se levanta derecho aquel humo en forma de columna o pirámide y descuella sobre las copas de los árboles más elevados. El día 20 de Agosto, que ese año fuera fatal para nuestra Monarquía por la pérdida de la batalla de Zaragoza ${ }^{35}$, se resolvió el Gobernador a continuar la marcha al Río Grande, después de haberse -352- cantado con la solemnidad posible Misa del Glorioso San Bernardo segundo, Patrón de la Ciudad de Salta, residencia ordinaria de los Gobernadores. Precedían los gastadores, que abrieron con hachas el camino, por ser todo aquel camino un continuado bosque, incapaz de talarle con fuego, por no haber pasto en que se cebe debajo de los árboles, y sólo se encuentran algunos palmares y cortas campiñas, que aún con no tener árboles. Estaban pobladas de continuos y multiplicados hormigueros, los cuales forman las hormigas sobre el haz de la tierra, levantando esta tan alta que parecen hornos de pan, providencia que el Autor de la naturaleza enseñó a estos animalejos para que en tiempo de verano, cuando son continuas las lluvias y se aniega [sic] toda la tierra, queden sus casas libres de la inundación del País. Estos hormigueros retardaban sobremanera la marcha, porque era menester rodear mucho para evitarlos, pues los Caballos no pueden pasar sobre ellos, ni menos el carruaje, porque se hunden en sus concavidades y los que se han endurecido, es preciso derrumbarlos con picos y azadones, por no aventurarse a sus ruinas. Padecióse de gran falta de agua en esos días, porque al paso que el terreno en tiempo de verano está inundado, en tiempo de invierno es sequísimo por extremo. Hallaron por estos parajes despoblados grandes rancherías de la Nación Aguilote, que al primer rumor de entrar las armas Españolas al Chaco, las abandonaron, persuadidos del famoso Notivirí, con quien se retiraron los Abipones. Llegaron finalmente al Río Grande el día 27 de Agosto, donde ya habían llegado antes los Tercios de Tucumán y Salta, y por su frontera, el de Jujuy. Mientras en el Río Grande se entretiene el Gobernador en formar el Fuerte de San Ignacio, seguiremos la marcha de los otros Tercios.

\section{\&. LXIX}

\section{PROSIGUE LA MATERIA DEL PASADO}

-353- Los Tercios de Salta y Tucumán, que salieron por el mes de Junio, como los demás caminaron con buen orden cada uno por su rumbo distinto. Los Tucumanos llegaron el día 19 al Río del Valle, y dejando el bagaje en un paraje llamado la Cruz del Eje, se avanzaron con caballos ligeros, que dieron en una numerosa Ranchería de Mocovíes, de quienes siendo sentidos, huyeron al bosque cercano, desamparando la ranchería con todo cuanto en ella tenían, que les apresaron los Españoles con treinta caballos, que también habían dejado. El día 21, atravesaron desde el Río del Valle hacia el Norte, por una selva bien espesa que tenía más de treinta leguas de largo, y salieron a las costas del Río Dorado, por donde subiendo hacia el Poniente, a cuatro leguas dieron en otra numerosa Ranchería de Mocovíes, que se componía de más de trescientos fogones, y serían según eso más de mil almas. Venían a este tiempo los Salteños por las cabezadas del Río Dorado, 
en número de 140 hombres, que se habían destacado [sic] de su Tercio, y viendo cierta humareda, presumieron lo que era, que los Tucumanos habían dado algún avance. Apresuraron la marcha y llegaron al mismo tiempo que asaltaban los de Tucumán, con quien el día 21 se hallaron de noche interpolados los de Salta. Todos fueron sentidos del enemigo; pero no obstante lograron cuatro prisioneros, de que mataron al mayor, reservando la vida a una mujer, a un muchacho de catorce años y a otro Indio, por ser ladino en lengua Quichoa. Llevaban los Españoles del Tucumán por Intérprete, para entenderse con estas Naciones, un Indio de Nación Malbalá llamado Antonio, que en su barbarismo se decía Ays, al cual había apresado el año antecedente el Maestre de Campo Don Antonio de Alurralde, y le había remitido a la Ciudad de Buenos Aires, para que lejos de los suyos aprendiese la lengua Castellana y se aficionase al trato de los Españoles, como se consiguió, habiéndoles cobrado Ays, o Antonio -354- (que así le llamaremos en adelante) grande afición, según lo mostró en la fidelidad con que se portó en toda esta campaña, siendo el principal instrumento de la pacificación de toda la Nación Malbalá, como se dirá después. A este hicieron que escuchase atentamente lo que hablaban los enemigos que estaban retirados en el bosque, porque toda aquella noche pasaron gritando al Español y con grandes aparatos de guerra, para que imaginasen los Españoles, como sucedió tenían asegurada la presa, y en el ínterin tuviesen tiempo de retirar su chusma. A esta sazón habló en castellano uno de los enemigos desde el bosque, de quien dijo el Malbalá Antonio era un Cristiano llamado Ignacio. Respondiole por su nombre el Maestre de Campo Alurralde, y él dijo había nacido y criadose en la Estancia de San Ignacio, que es la hacienda de nuestro Colegio de Santiago del Estero, siendo hijo de una cautiva mocoví, a quien dejó para volverse adonde estaba el resto de su parentela: que como no le matasen, saldría por la mañana del bosque a tratar de la paz del Mocoví con los Españoles, porque aquellos enemigos se querían ya hacer amigos de una vez. No tenían los Mocobís tales intentos, sino que todo era por dar tiempo a que huyesen y se retirasen y él con ellos, como lo ejecutaron, por más que el Maestre de Campo Alurralde le exhortó a que dejando su infeliz apostasía asegurase su salvación, reduciendo aquella gente a la amistad que ofrecía. El día siguiente por la mañana, al romper el nombre [sic] los Españoles de ambos tercios, hizo la misma diligencia el enemigo, tocando varios instrumentos de guerra a su usanza, y con grande algazara cogió su marcha el bosque adentro. Era imposible seguirles por la impenetrable espesura; pero no obstante, se quedó solo a observar nuestros movimientos el Cacique Queguachy, bien ladino en la lengua Quichoa, a quien requiriéndole de lejos con la palabra que había dado Ignacio, tiró con sus respuestas a entretenernos, por lo cual, por medio del prisionero de su Nación y del Malbalá Antonio, se le hizo saber el poder grande con que estaban los Españoles y la resolución de perdonarles sus atrocidades pasadas si admitían la paz. Oyolo Queguachy y sin darles respuesta, porque al conocer estarían los suyos en distancia competente, y puestos en -355- salvo, se desapareció, y por más que se trabucó después todo el bosque por varias partes, no se le pudo hallar, como tampoco a los suyos, que guiaba Ignacio.

39 Aunque este apóstata logró su traza en esta ocasión, deslumbrando a los Españoles, no pudo librarse de la ira Divina, que le castigó su obstinación si misericordia; porque le había hecho indigno de ella con sus grandes delitos. Capitaneaba a los Mocovís trayéndolos a la Frontera de Salta para los robos, muertes y estragos que se ejecutaron los años que vivió entre ellos este Apóstata, y para mejor disimularse y poder entrar a su salvo en las tierras de Cristianos a asegurar mejor los lances en nuestro descuido, no se había pelado la frente, barbas, cejas y párpados como acostumbran los Mocovís: vivía 
como hombre sin Dios amancebado con otra India Cristiana, que estuvo cautiva en Tarija, y era de Nación Paloma, a quien huida de aquella Villa, habían vuelto a cautivar los Salteños en esta guerra. Diole el Cielo varios avisos para que se enmendase, y todos los despreció protervo, hasta que llenándose el número murió en su maldad el año de 1712, dos después que usó el engaño referido; porque como una noche hubiese robado en el Presidio de Balbuena la caballada que estaba pasteando en la campaña contra el orden del Gobernador, que tenía mandado se encerrase de noche en corral, porque no se diesen armas a los enemigos si la robasen; el Capitán de aquel Presidio Don Joseph de Mercado, que tenía a su cuidado la caballada, temeroso del castigo que ejecutaría el Gobernador por no haber obedecido su orden, salió luego a la ligera con diez Españoles y once Indios Lules en seguimiento del enemigo, que llevaba robados los caballos. Alcanzóles Mercado y recobró la caballada, habiendo antes disparado un balazo al caudillo Ignacio, a quien derribó herido de su caballo, pero aún de esta manera con un grande alarido avisó a la Ranchería cercana para que se pusiesen en cobro $^{36}$. Ignoraba Mercado que el herido fuese Ignacio el Apóstata y apeóse para acabarlo a puñaladas; pero suspendido por ver si hallándose en aquel trance descubría donde estaba la Ranchería; porque es increíble cuan grande secreto guardan eb este particular, y queriendo antes dejarse matar, que [356] descubrir donde tienen su morada, para que no aprese el Español la chusma de niños y mujeres. Antes de responder el Apóstata, preguntó al Capitán quién era: respondió que el Capitán Mercado. Al oír ello, exclamó el Apóstata: a Dios [sic] Ignacio, de esta vez acabarás con tu vida; porque era grande la fama de valiente que el dicho Mercado tenía por sus proezas entre todos los bárbaros del Chaco. Instóle el Capitán le dijese dónde estaban su Ranchería; porque si le engañaba o no se lo descubría le había de matar sin remedio, cosiéndole allí a puñaladas. Aún a vista de tamaño riesgo tuvo ánimo para mentirle por no hacer daño a los suyos, y mostró la senda contraria al Capitán que, hallándose burlado, volvió y le mató con su propia macana, castigando Dios [los Españoles: la mano de Dios] de esta manera la apostasía de aquel malvado, que tantos años conspiró con los Indios Infieles contra el Pueblo Cristiano: y su muerte y su muerte se reputó como una gran victoria, que perdonándole el Gobernador la desobediencia y la tenacidad de haberse arrojado con tan poca gente al centro del enemigo vencido de su pundonor, le premió el Capitán Mercado haciéndole Sargento Mayor del Real Presidio de Balbuena; porque en matar a Ignacio libró a la Frontera por muchos años de las invasiones de los otros Bárbaros.

No difirió tanto el Cielo el castigo de otro Apóstata semejante de la misma Nación Mocoví, que era aquel Indio a quien habiendo aprisionado los Tucumanos y Salteños en la Ranchería donde se encontraron y dijimos habían perdonado la vida, por ser ladino en lengua Quichoa. Llamábase Jacinto, y por leve causa había apostatado de la Fe y retirádose al Chaco, lo que sabido de los Jefes de Salta y Tucumán, le mandaron quitar la vida, para lo cual le dieron un balazo, de que cayó en el suelo, donde los Indios Amigos le flecharon y aún herido de bala y flechazos estaba con tanto ánimo, que se sacaba las flechas como si no tuviera la más leve herida, y al darle un bote de lanza por los pechos se agarró de ella y murió sin dar el menor indicio de cobardía o temor.

De este paraje del Dorado, donde acaeció lo referido, determinó la gente de Tucumán y Salta después de diversos pareceres tirar derechos al Río, para lo cual encaminaron -357la jornada a los manantiales del Palmar, donde tenían noticia estaba rancheado Ylimi, Cacique de la Nación Mocoví, con muchos de los suyos; pero aunque hallaron señales de haber habido por allí mucho gentío, no encontraron infiel alguno, ni menos agua, de que 
padecían mucha falta, después de haber pasado con solo bizcocho duro la vigilia de San Juan Bautista. Por la falta de agua protestaron los Capitanes de Tucumán y la soldadesca pagada del Presidio de Esteco a su Maestro de Campo Alurralde el manifiesto peligro de perder la vida, no a manos de enemigo sino a violencias de la sed a que los exponía; obligado de la protesta, determinó retroceder al Río Dorado, pero la gente de Salta se animó a pasar adelante, y a una legua hallaron al otro día agua suficiente y otra aguada copiosa más adelante en un pozo, que llamaron de San Juan Bautista; así, por ser día del glorioso Precursor, como por atribuir a su intercesión el haberse hallado, pies en el mayor peligro de perecer. Se encomendaron muy de veras al Santo, pidiéndole encarecidamente les deparase alguna aguada donde refrigerarse. Allí se atrincheró el Capitán Don Francisco Arias con cuarenta y nueve Españole, y los demás se avanzaron al Río, siguiendo a la ligera a los enemigos que ya habían pasado al dicho Río, y queriendo pasarle también los Salteños en su alcance, no se halló vado, el cual fue a buscar Río abajo un Soldado, llamado Julián Ramos, pero no le pudo hallar, a cuya causa mandó el Maestre de Campo Lisperguer se parase en una ranchería que acababa de desalojar el enemigo, ínterin que se disponían balsas para pasar el Río. Salieron aquí unos Soldados a buscar leña, y el que hacía centinela de escolta, llamado Felipe de Leyva, vio venir hacia sí un Indio a mula, a quien queriendo disparar un balazo, erró fuego la escopeta: lo cual, reconocido por el Indio, le tiró un dardazo a los pechos, que a no ser por el coleto tan fuerte le hubiera pasado de parte a parte. Estrechóse entonces Leyva con el Infiel, y ayudado de Juan Razero, otro Soldado Español de los leñadores, le ataron entre los dos y condujeron al Real. Venía armado con su dardo y flechas y yendo siguiendo a los suyos, que huían de los Españoles, se vino a entregar para que en hacerle prisionero se entretuviesen estos, [358] salvase y librase mejor a los de su Nación. Pidioles que no le matasen; porque él era un Indio flojo, que a nadie hacía daño, y se mostró muy apacible y humilde, hablando con grande sumisión a todos en la lengua general del Cuzco. Todo esto era disimulo, para conseguir mejor sus intentos y trazas de asegurar a los suyos; porque en la realidad era Indio valiente, ladino, astuto y sagaz, que acaudillaba a una parcialidad de Mocovíes, que asistía a su Cacique Anegodí: llamábase Coquini, que había ejecutado grandes estragos en la Frontera, y con su artificio supo entonces y después, tener embaucados a los Españoles de Salta, y aún disimular quién era, hasta que le descubrieron Antonio el Malabalá, y la Paloma prisionera con harto pesar suyo. Para avistarse con ellos, enviaron los Salteños al dicho Coquini al Tercio de Tucumán, donde luego que le vio el Malbalá Antonio, dijo era Capitán Coquini, compañero de Anegodi, y el mayor caudillo que tenían los Mocovís. Hacíale señas el prisionero, poniendo los dedos sobre la boca, como que le decía otra cosa; pero el fiel Malbalá siempre se ratificó en su dicho, con que el infiel se vio precisado a contestar era Coquini, aunque negó arrestado ser Cacique ni caudillo; y quedó tan sentido de verse descubierto, que vuelto al Real de Salta, no quiso esa noche cenar ni dormir de pesadumbre.

El dicho Tercio de Tucumán, después que se separó de el de Salta por la falta de agua, retrocedió hasta el Río del Valle, donde encontró su bagaje, y el de Salta tomó algún refuerzo. Prosiguió Río abajo del Valle para salir al antiguo Fuerte de San Simón, dos leguas más abajo, de donde salió el bagaje de Salta, que tiró por las cabezadas del Río Dorado. Al atravesar este Río despachó el Maestre de Campo Alurralde a su Sargento Mayor Simón García Valdés con 130 hombres, a reconocer el camino y aguadas y ver dónde tiraba la huella del enemigo: halló poca aguada para el bagaje y reconoció la astucia de los bárbaros en su fuga, pues fingiendo se retiraban a tierra de los Lules, era solo para guarecerse por allí del bosque, pues luego torcían con disimulo al Río Grande 
por la espesura impenetrable. Por eso tiró allá derecho el destacamento, y llegó el día once de Julio, y al siguiente caminaron costeando -359- el Río hacia el oriente, hasta llegar al paraje donde decía Antonio el Malbalá se retiraban los suyos cuando sentían al Español; pero no hallaron persona alguna de dicha Nación. Aquí, considerando que el mantenimiento escaseaba; que las cabalgaduras podían llegar a rendirse de una vez, y que los enemigos se podían incorporar si se les daba tiempo, y cogiéndoles faltos de caballos lograr su osadía, se resolvió el Sargento mayor con el parecer de todos los Cabos a retroceder por la costa del Río Grande a incorporarse con el tercio de salta, para seguir juntos la huella de los infieles por la otra banda a donde se reconoció habían pasado fugitivas todas las Naciones. Así que retrocedieron buscando paraje cómodo donde poder construir el Fuerte en que dejar el bagaje asegurado, el cual conducía el Maestre de Campo Alurralde, con quien se topó su Sargento mayor en la misma costa el día 16. Gastaron cinco días en fortificarse, y el 22 salió el Maestre de Campo con 130 hombres a incorporarse con el tercio de Salta para pasar el Río Grande a seguir al enemigo. Avisó con un correo al Maestre de Campo Lisperguer los intentos de su marcha, que eran de pasar a la otra banda a seguir a los enemigos. Repugnábalo Lisperguer, porque su ánimo era esperar al Gobernador, entreteniéndose en acabar el fuerte, ínterin que llegaba Su Señoría; pero reconviniéndole el Maestre de Campo Don Juan de Lizondo con el orden del mismo Gobernador, hubo de conceder lo que pedían los de Tucumán. Construyóse pues el Fuerte de Salta, que se llamó de San Juan y salió obra perfectísima, y llegado el Maestre de Campo de Tucumán, señaló el de Salta ochenta Soldados de su Tercio, con quienes determinó pasar a la otra banda en persona, acompañando a la gente de Tucumán.

\section{\&. LXX}

\section{PASAN EL RÍO GRANDE LOS ESPAÑOLES DE TUCUMÁN Y SALTA Y PACIFICAN LA NACIÓN MALBALÁ}

-360- Resueltos a pasar a la otra banda del Río, los Salteños y Tucumanenses dispusieron balsas y pelotas de cuero, en que ejecutar el pasaje por haber entre ellos pocos nadadores, y se ejecutó el transporte tan felizmente el día 23 de Julio ${ }^{37}$, que sólo hubo la pequeña pérdida de cuatro caballos, que se ahogaron. El día 24 empezaron a caminar por la ribera hacia el Oriente, y después apartándose algún trecho de la costa, penetraron por bosques tan espesos que era necesario fuesen delante los gastadores abriendo camino con hachas; otras veces pasaban por pantanos muy hondos, en que era preciso detenerse a hacer puente para poder caminar; otras por barrancas tan peinadas, que a punta de lanza formaban escalones, por donde pudiesen bajar y subir los caballos. En todo esto no se ofreció lance considerable. Sino que de cuando en cuando se dejaban ver algunos infieles, que sin duda eran espías, para observar nuestra marcha, y por más que se procuraba dar alcance era en vano porque ganaban luego la espesura, por donde a ellos les es facilísimo escaparse, por la costumbre que tienen de emboscarse, y llevar muy poco embarazo, cuando al Español le es imposible penetrar. Conociendo eran sentidos los Españoles del enemigo, se determinó pasase a la ligera en su alcance por los rastros frescos la vanguardia, que conducía Don Francisco Arias, Capitán de una compañía del Tercio de Salta, alternando con la compañía del Capitán Don Francisco Ruiz de Villegas. Y así caminaron hasta unas chacras o sementeras, que dijo el Malbalá Antonio eran de sus parientes. El día 28, después de haber caminado la vanguardia diez y seis leguas a la ligera, al ponerse el Sol dio alcance al enemigo, que se acababa de alojar, y como les 
dividía de los nuestros una alta barranca, esperaron a los nuestros, provocándoles a pelear, porque tuvieron tiempo para disponer sus cosas por -361- haber sus centinelas sentido desde lejos a los Españoles. Eran estos infieles de Nación Malbalá, que no imaginaron poder ser ofendidos fácilmente de los Españoles, cuando súbitamente les embistieron estos, algunos a caballo y los más a pie, porque no daba el bosque fácil entrada. Mataron siete infieles y apresaron ocho después de derrotarles enteramente y hacerlos huir a todo el resto a pie, porque se les quitaron ciento y cincuenta cabalgaduras y también algunas ovejas, que fue socorro muy oportuno, porque ya se hallaban los soldados con sobrada escasez de víveres. De los despojos de aquella Nación cogió cada uno lo que más le agradó, y lo restante de su menaje se condenó a las llamas, que tuvieron en que cebar su voracidad un día entero. De los nuestros, hirieron de un flechazo a un Soldado Español, que se llamaba Antonio Rodríguez y los enemigos se arrojaron al Río y pasaron a la banda del Sur. Otorgóse la vida a los que se apresaron vivos, porque el Malbalá Antonio, que con tanta fidelidad favorecía al partido de los Españoles, intercedió por estos, ofreciendo que toda aquella su parcialidad se reduciría a la paz, como en efecto sucedió, y se dirá después. Acabada la derrota, dejó el Maestre de Campo Don Juan de Lizondo al Sargento Mayor Don Agustín Martínez de Iriarte en guarda de la presa, y escogiendo cincuenta Soldados partió tras el enemigo; pero como éste había ya pasado el Río, se hubo de volver a los tres [sic] a buscar la retaguardia, que encontró el mismo día de nuestro Patriarca San Ignacio, a la cual en su marcha vinieron gritando unas espías enemigas, a quien no se pudo ofender por estar amparadas de una gran laguna inmediata.

No obstante, el vigoroso avance y derrota referida, obligó a rendirse la Nación Malbalá, y a hacer paces con los Españoles, lo cual se empezó a ejecutar de esta manera. Entre los prisioneros Malbalaes había una india muy anciana, propuso Antonio el Malbalá que despachando esta a los suyos, ellos vendrían a asentar la paz. Consultóse si sería conveniente despacharla, y como se aventuraba tan poco en soltarla, cuando se podía interesar tanto si surtiese efecto la diligencia, convinieron todos en que se le largase luego. Despacháronla bien provista de comida -362- y cabalgadura, dándole Antonio Malbalá sus instrucciones. Como seis horas después se divisó un jinete, de que dio aviso la centinela que estaba subida en un árbol muy alto. Diósele orden se le dejase acercar si venía solo: llegó y entró desalado ${ }^{38}$ al Real de los Españoles, sin el menor recelo. Dijo ser el padre del Malbalá Antonio, que habiendo salido a buscar vitualla para sus hijos se encontró accidentalmente con la vieja, que le dio noticia cómo vivía su hijo Ays, a quien todos los suyos daban por muerto, y por esta razón su mujer se había casado ya con otro Indio: que había sido grande el gozo recibido con esta nueva, que no le había sufrido el corazón volver a su ranchería antes de ver a su hijo muy amado. Luego que este reconoció a su Padre, viéndole desnudo, se despojó de la anguarina ${ }^{39}$ y se la dio para cubrirse con edificación de los presentes, al ver el bárbaro tal piedad. Hablaron muy despacio Padre e hijo, y este le refirió el buen tratamiento que había hallado entre los Españoles, la buena vida que entre ellos se pasaba, sin los sobresaltos que hay de continuo en su Nación por las guerras que traen entre sí y con otras Naciones: la abundancia de mantenimientos y ropa para comer y vestir y otras conveniencias semejantes, que mueven mucho los ánimos viles y apocados de este gentío, las cuales les debían reducir a asentar la paz y rendirse a las armas españolas. Oyóle el Padre con señales de agrado, mostrando deseos de que se efectuase. Había dicho Antonio antes de venir su Padre, que los suyos admitirían la paz y alianza con los Españoles, con tal que los situasen sobre el Río Valbuena, porque era antigua pretensión suya ranchearse en aquel paraje, de donde los echaron los 
Mocovíes, y les quemaron sus ranchos, y los Malbalaes solían ir a la Frontera de Salta a hostilizarla. Volvióse ahora a tocar el punto con el Padre de Antonio, y creen muchos que desde luego se lo ofreció el Maestre de Campo Alurralde, aunque las relaciones sólo dicen que se le respondió que viniese su Cacique, con quien hablarían y pasarían a ver al Apu grande (que así llaman estos bárbaros al Gobernador) para que lo determinase, que suspenderían las armas contra ellos, alojándose ocho o diez leguas de nuestro Real Río Grande abajo, durante la campaña; pero que ellos, ni sus -363- hijos no habían de huir la cara al Español, como acostumbran. Ofrecióse el Bárbaro a dar fielmente el mensaje a su Cacique, que era su yerno, y se partió luego a ejecutarlo para traer en breve la respuesta, y juntamente a otro hijo suyo, para que viese a su hermano Antonio, quedando los Españoles muy consolados y dando infinitas gracias al Señor por esperar tan en breve algún logro de sus trabajos.

Pasó esto en la retaguardia antes de llegar de vuelta el Maestre de Campo Lizondo el día 29 de Julio y al siguiente día a las ocho de la mañana, que era la hora pactada por el viejo, llegó puntualmente con su hijo mocetón de veinte años, y dio razón cómo la vieja despachada el día antes había pasado en busca de los maridos de dos prisioneras Malbalaes que habían cogido los Españoles en el avance de su Ranchería, y que su Cacique quiso venir al Real de los Cristianos, porque deseaba ardientemente asentar con ellos de una vez perpetua paz y amistad, y desistir de la continua guerra que cada día traen unos con otros; pues si cuatro días están amigos, lo más común es aborrecerse y pelearse como enemigos capitales; mas que no obstante estos deseos había suspendido la venida; porque su hija la mujer del Cacique tenía todavía sus desconfianzas, y por no disgustarla le había rogado volviese otra vez al Real de los Españoles, y según se fuese, se determinaría a hablarles. Fue el gozo más crecido, porque ya iba tomando cuerpo el negocio. Dieron algún vestido al hermano de Antonio, y Padre e hijo se volvieron muy contentos, diciendo el viejo tuviesen por cierto vendrían los maridos de las prisioneras, y por señas harían humos, a que rogaba les respondiesen con otros. Los Españoles trataron de caminar, porque su bastimento era ya poco; y estándose alojando, vieron la seña del humo, a que respondieron puntuales con que llegaron sin recelo con la vieja que se soltó dos Indios, que el uno era marido de una prisionera y otro su Padre, que dijeron ser Capitán llamado Jonays, y que a poca distancia venían otros dos Malbalaes a pie, por no haberles quedado del avance cabalgaduras, y en breve llegaron y entregaron al punto sus armas: el uno era marido de la otra prisionera, y el otro su Padrino, los cuales -364- entraron al Real muy gozosos por hallar vivos a los suyos, y el Capitán Jonays presentó su dardo al Maestre de Campo Alurralde en señal de paz y amistad.

A poco rato, que ya era de noche, se vio otro Indio: salieron los Españoles, y los Malbalaes dijeron que bien podían matarle porque no era de los suyos, los cuales venían muy atrás por falta de cabalgaduras. Sacaron al prisionero Coquiny para que a su usanza los llamase del bosque donde estaban defendidos. Llamóle a su modo con un silbo y respondió el otro con dos, por los cuales conoció Coquiny era de los suyos, y que se llamaba Apotquein; cómo al contrario conoció este que era Coquiny y le llamó por su nombre, que es maravilloso modo de entenderse. Pusieron de secreto al Malbala Antonio en parte donde les pidiese oír su parlamento; sin saber Coquiny quien le escuchaba empezó a hablar a Apotquein con gran fervor y éste a responder y repreguntar, y en sustancia se redujo la conversación, según convinieron en lengua Quechua Coquiny y en la Castellana Antonio, a preguntar el prisionero por su mujer e hijos, a que le satisfizo Apotquein con decir estaban cerca del Fuerte de San Juan del Tercio de Salta. Rogóle Coquiny viniese al Real sin temor de los 
Españoles, que no le habían hecho daño alguno, antes decían les admitirían a su amistad como viniesen todos, y por el contrario, si no se rendían, les harían cruda guerra hasta acabarlos. Preguntóle Apotquein qué modo de marchar guardaban los Españoles, y respondió Coquiny que eran muchos y no sabían dormir de día ni de noche, sin rendirles trabajo alguno, y que tenían hechas casas donde había otros muchos, mas como aquellos los cuales conspiraban todos a acabar con la Nación, que otros venían con el Apu grande, otros con el Capitán de Jujuy, otros por Tarija con los Chiriguanás, y otros finalmente por el Río Grande abajo, sobre los Guaycurús: con que el caso no tenía ya otro remedio que sujetárseles, si no querían temerarios perecer. Dijo entonces Apotquein a Coquiny que le llamase al Apu, porque de miedo no se atrevía a entrar al Real a hablar, acudió pronto el Teniente de Salta Lisperguer, y llamóle por su nombre. Respondió Apoteiquin en Castellano Señor, y añadió en su lengua -365- que después le volvería a ver. Cesó con esto el razonamiento, quedando Coquiny gozoso con la esperanza de ver algún día a sus hijos y mujer, pero como después se averiguó todo, fue astucia de este malvado, por ver si podía descuidar a los Españoles, aunque no lo consiguió, y el Apotquein, infiel a sus promesas, como todos los de su Nación mocoví, jamás se dejó ver, antes se cree fue a retirar y esconder en partes remotísimas toda su chusma. Así se cerró el día de Nuestro Gran Patriarca, que fue felicísimo para dos párvulos, que en nombre de su Nación Malbalá fueron los primeros que entraron a la dicha de ser Cristianos, siendo ambos bautizados con el nombre de Ignacio.

47 A 1 de Agosto siguieron los Nuestros su derrota, y en los días cuatro y cinco pasaron el Río, encaminándose cada destacamento a su Fuerte, que distaba uno de otro dos leguas a esperar bastimento, de que llegaron a padecer tanta penuria que sólo comían cueros y algarroba zorruna. En busca de bastimentos salió el Maestre de Campo Lisperguer, dejando solos 60 hombres de guarnición en el Fuerte de Salta, a cargo del Maestre de Campo Lizondo, y llevando consigo una escuadra del Tercio de Tucumán para el mismo efecto, comandada del Sargento Mayor Don Ramón García Valdés, a causa de no poder ir en persona el Maestre de Campo Alurralde, que poniendo treinta hombres de su tercio, con otros tantos de el de Salta, de los que habían quedado en el Fuerte de San Juan se despachasen en busca del Maestre de Campo del Tercio de Jujuy Don Antonio de la Tijera, de cuya marcha, aunque no habían tenido la menor noticia, discurría no poder estar muy lejos y les podría socorrer, para que no pereciesen de hambre; pero rechazó Alurralde cortésmente este arbitrio, lo primero: por tener muy flacos los caballos; lo segundo por ser incierto encontrar el Tercio de Jujuy; y lo tercero por la cautela con que se debe proceder con los infieles, de cuyas traiciones hay tantas experiencias, pues divididas las pocas fuerzas Españolas que allí habían quedado, podían invadirles en tanto número que no se pudiesen defender. Mientras esto pasaba, aparecieron en el Fuerte de San Juan cuatro Indios, a quienes salió al encuentro con 20 -366- Españoles el Maestre de Campo Lizondo: entonces dijeron ellos amigos, que era la contraseña que se les había dado para conocer que eran Malbalaes y distinguidos de las otras Naciones enemigas. Acariciároslos en el Fuerte, y ellos dieron noticia cómo la chusma de mujeres, niños y otro gentío de los suyos quedaban atrás, caminando poco a poco a pie y buscando de comer, porque en el avance, que el mismo Lizondo les dio, habían quedado imposibilitados, pues les robaron entonces las cabalgaduras y todas las vituallas. Uno de estos era [el] Cacique llamado Jonapayn, a quien trajeron los suyos para tratar la paz. Venía vestido de una camiseta labrada de varios colores: en los puños traía brazaletes y de sus orejas pendían dos arracadas labradas de cuentas de vidrio, y borlas de varios colores; otro era el hermano de Antonio, quien traía una hermosa corona de plumas de color. De que pendía un bizarro 
penacho. Otro era el Capitán Oonays, muy nombrado entre todos los de su Nación. El cuarto era un indio pariente de ellos, que a la primera vista imaginaron los Españoles era mujer, o de otra Nación, por lo que se diferenciaba de los demás en el cabello, pues usando esta Nación cortársele, este le había dejado crecer. Llevados de la curiosidad los Españoles quisieron saber la causa, y preguntado, respondió era uso entre ellos y rito indispensable (según dijimos en el \&. 13) el dejarse crecer el cabello en señal de duelo y sentimiento por la muerte de sus parientes, uno de los cuales se le había muerto meses antes. Después de haberles dejado descansar, y dado de comer, los condujeron algunos Cabos Reformados al Fuerte de Tucumán, en cuyas cercanías se habían de alojar por haberse rendido al Maestre de Campo Alurralde. Sólo se tuvieron tres días entre los Españoles, porque les precisaba la vuelta a los suyos, para guiarlos y certificarles cuan bien eran tratados del Español. En el ínterin se ponía todo empeño en el Fuerte de San Juan, para concluir una Capilla, que traían entre manos, para dedicarla su día al Invicto Mártir Español San Lorenzo, y para ello se emplearon todos los soldados que habían quedado de guarnición con celo religioso, y piedad cristiana en el adorno de la casa de Dios, esperando por este medio conseguir la pacificación de todo el bárbaro -367- gentío , para cuyo efecto se congregaron con una gloriosa y santa emulación, queriendo cada uno exceder al otro; singularizándose no obstante en tan piadoso empeño los Maestres de Campo Elizondo [Lizondo], Iriarte y Castellanos, el Sargento Mayor Don Joseph Fernández y el Capitán Don Antonio Peñalba, que personalmente cuidaron de todo el adorno que permitían las circunstancias, con que pudo decir en la Capilla la primera misa solemne el Padre Balthasar de Texeda, el día diez de Agosto con grande júbilo y alegría de todo el Real.

Acabada la Misa aparecieron seis Mocovís en frente del fuerte de San Juan de la otra banda del río Grande, y aunque al principio temieron pasar, por más que le aseguraban los Salteños de toda hostilidad, al fin resolviéndose uno le siguieron los demás, y los recibieron con las armas encubiertas por que no se atemorizasen. Hablaron con Coquiny, oyéndoles de secreto el Malbalá Antonio, a quien dijeron se vendrían todos con sus mujeres y chusma, lo que conseguirían fácilmente, en especial el uno de ellos llamado Talexmati, Caudillo y Hermano de Anegody, Cacique principal de la Nación Mocoví. Confirmóles al parecer en su determinación el astuto Coquiny; pero a la verdad todo era engaño, así para registrar el campo Español, como para entretenerle no facilite a hacer correrías, según mostró la experiencia. Al contrario los Malbalaes siempre estuvieron fijos en su primer resolución, y por que no se dudase de su fidelidad, viendo tardaban los suyos vino a entregarse en rehenes el Cacique principal de toda la Nación llamado Jonastete; aunque haciendo de él confianza, le dejó volver el Maestre de Campo Alurralde. Por fin se llegó el día feliz, en que se entregó la principal parcialidad de la Nación Malbalá, que fue Sábado 16 de Agosto. Tuvo noticia anticipada de que estaban cerca los Malbalaes el Maestre de Campo Alurralde y salió a recibirlos acompañado de veinte Españoles. El Cacique Jonastete los esperó teniendo pues en ala más de cien familias de su Nación que, al avistar a los Españoles, empezaron a hacer cierta armonía, poniendo las manos en la boca, que es entre ellos señal de alegría y de paz. Vinieron al Fuerte del Rosario [Fuerte de Esteco o de Nuestra Señora del Rosario ${ }^{40}$ ], y aunque cuando se despidió el Cacique se le -368- había dado licencia para alojar su gente donde más gustase, no obstante pidió ahora de nuevo se les señalase donde formar su ranchería, como lo ejecutaron, y los días siguientes fueron llegando otros de la misma Nación que habían quedado atrás, por no poder seguir la marcha de los primeros. A los cuatro días sucedió un lance imprevisto, que hubo de desbaratar cuanto se hubo trabajado en la Reducción de los Malbalaes. Como los 
dos Fuertes de Salta y Tucumán estaban tan escasos de bastimentos, no tenían qué dar a los nuevos Aliados para su manutención hasta que llegara el socorro. Venía con él desde el Río del Valle el Sargento Mayor Don Simón García Valdés, a tiempo que algunos Malbalaes andaban cazando en el bosque. Topáronse con ellos los Soldados de la partida que traía el convoy, ignorantes de que dicha Nación estaba ya de paz: por lo cual apresaron a algunos que pudieron y escapándose los otros, vinieron al Real y causaron grande alboroto, juzgando les quería engañar el Español, que como estas Naciones generalmente son pérfidos y no guardan la fe que prometen, fácilmente sospechan lo mismo del Español, y más donde había fundamento de haberse apresados [sic] sobre seguro. Discurrió luego el Maestre de Campo Alurralde lo que podía ser, y haciendo poner su gente en arma salió a sosegarlos, y llegando los prisioneros los hizo soltar: con que se aseguraron de la sinceridad con que procedían los Españoles y conocieron había ocasionado aquel suceso la ignorancia de la amistad pactada entre ambas Naciones. Con el nuevo convoy se proveyó abundantemente a los Malbalaes, que el día 27 de Agosto salieron a recibir al Gobernador, y asentar las capitulaciones de paz, como ya se dirá.

\section{\&. LXXI}

\section{CAPITULAN LOS ESPAÑOLES LA PAZ CON LA NACIÓN MALBALÁ}

-369- Luego que el Maestre de Campo Don Antonio de Alurralde se aseguró [de] que los Malbalaes trataban de veras el negocio de la paz, procuró dar aviso al Gobernador, quien con esta noticia apresuró la marcha al Río Grande ${ }^{41}$. Sabido por Alurralde que distaba ya su Señoría sola una jornada, determinó salir a recibirle con algunos Malbalaes, para que le rindiesen obediencia, y con previo aviso del Gobernador, dispuso fuese el encuentro en una despejada campiña, donde pudiesen ver los Infieles toda la marcha Española acordonada, para que reconociesen era verdad cuanto se les había asegurado de nuestras fuerzas, y les causase tal terror, que perseverasen firmes en su deseo de nuestra amistad. Así se ejecutó: salieron a esperar en aquella campiña Jonastete, el Cacique principal, y quatro Caciques menores Leadí, Jonais, Leatí, y Jonapain; seis Capitanes Netaichí, Elac, Quetés, Jonom, Nectacquechi, y Taclete Ilis, Padre de Antonio con sus dos hijos, y la India, que fue por mensajera, à quien llamaban la Conquistadora; porque con sus buenas razones inclinó a su Nación a la paz. Acompañábalos el Capitán del Tercio, el Maestre de Campo Alurralde, $\mathrm{y}$ diez Reformados. Estaban los Malbalaes a caballo muy galanes à su modo, y con ceñidores colorados esmaltados de lentejuelas de nácar muy vistosas ceñían sus cabezas,como si fueran diademas, y con plumajes de varios colores, que pendían desde la cintura, excepto el Cacique principal Jonastete, y Antonio el Intérprete de los Españoles, que venían vestidos, y la Conquistadora, cubierta con una manta de cueros. Al punto que divisaron los Malbalaes al Gobernador, se pusieron las manos en la boca, dando golpes en ella muy alegres, y haciendo su armonía. Hicieron la salva los Reformados al Gobernador con los fusiles; pero es tan horroroso el miedo que tienen concebido todas estas Naciones a las bocas de fuego, que aun con estar con la seguridad que prometía -370- unción, se tendían sobre sus caballos con ademanes de grande espanto. Adelantóse Jonastete, que llevaba en la mano un dardo negro muy lucido, y ofrecióselo al Gobernador con un papel, que iba enarbolado en la punta, y decía: Jonasteté Cazique de la belicosa Nación Malbala, vengo rendido a daros la paz en nombre de toda ella. Recibióle el Gobernador con singulares demostraciones de cariño, y benevolencia, dándole un estrecho abrazo, y por medio del Intérprete Antonio les dijo a todos, se alegraba de verlos, y que por haber venido primero, 
y rendídose a nuestras armas, les perdonaba los delitos y hostilidades, que hasta entonces habían cometido contra el Español. Dicho esto los despidió benignamente, y montando en sus caballos se retiraron a donde estaban alojados. El Gobernador con toda su comitiva enderezó la marcha al Fuerte del Rosario del Tercio de Tucumán, y siendo preciso pasar por el alojamiento de los Malbalaes salían las Indias viejas a festejar al Gobernador, y Españoles con grande algazara.

Tres días después partió el Gobernador al Fuerte de San Juan del Tercio de Salta, que distaba dos leguas del Rosario, allí hizo junta de guerra, para que convocó a los Jefes más expertos de ambos Tercios, con quienes consultó si se les había de admitir a los Malbalaes al Río de Valbuena, como ellos pretendían, para hacer su habitación; o si se les había de despachar a que poblasen en el Puerto de Buenos Aires para ser doctrinados: y caso que ni quisiesen ir a Buenos Aires ni se les debiese permitir poblarse en el Río de Valbuena, si se les había de dar libertad, para que se volviesen a sus tierras: Varios fueron los pareceres de los Consultores, algunos nacidos más del marcial ardor que de la prudencia, y política Cristiana. Porque uno dijo que no queriendo ir a Buenos Aires, se les dejase volver libre a sus tierras, y después se les hiciese rigurosa guerra, como si fuese muy fácil extraerlos de los espesos bosques, e impenetrables breñas, en que se guarnecen y esconden. El sentir de otro fue, que se degollasen todos los Gandules o adultos, y toda la chusma se llevase a Buenos Aires, si no de grado por fuerza. Otro arbitrio, que se les dijese irían a Valbuena, y puestos allá con este engaño, se les transportase a Buenos Aires con violencia. -371Rechazaron los demás Consultores estos tres pareceres. El primero porque era temerario, pues darles larga para hacerles guerra, parecía imprudencia manifiesta, e intento inasequible. El segundo por ser contra la fidelidad, y palabra de amigos, debajo de la cual se habían entregado principalmente los adultos, contra cuya vida maquinaba la muerte aquel arbitrio. El tercero por indigno de la verdad y Cristiandad, que profesan los pechos Españoles, que como valerosos abominan de engaños semejantes propios de gente habilitada y cobarde, y contrarios a la sinceridad, que prescribe la ley Evangélica. Por tanto los demás fueron de parecer fundados en la facilidad e inconstancia de este gentío, $\mathrm{y}$ en el defecto de que se lograsen con seguridad sus almas, que por medio de Antonio, pues era de su Nación, había vivido en Buenos Aires, y estaba muy pagado de las conveniencias de aquel País, se les inclinasen a que fuesen allá, como en tiempos pasados se transportaron los Quilmes desde el Valle de Calchaquí, porque de quedar en Valbuena se arriesgaba mucho su salvación; pues estando allá a la vista de sus tierras, podían con facilidad volverse a ellas, motivados de cualquier leve agravio que el Español les hiciese, por ser este gentío delicado, y sentido en extremo, o instigados de los Mocovíes en otro tiempo sus amigos nos podrían hacer terrible guerra prácticos del terreno, pero que si no obstante estos inconvenientes no se les pudiese reducir a que quisiesen pasar a Buenos Aires a ser instruidos en la Ley de Cristo, se les concediese el sitio de Valbuena, dándoles desde luego Misioneros aptos, y poniendo cerca de ellos un Presidio de Españoles, con quien tuviesen ellos poca o ninguna comunicación, ni con ellos los Españoles; porque de esta manera se atajaban los inconvenientes temidos, pues con la corta comunicación del Español, se cautelaban no fuesen de él agraviados y con el Presidio se les guardaba de los Mocovíes, y de ellos mismos a los Españoles si intentasen rebelión. No se inclinaron a ir a Buenos Aires, y así se les dio a Valbuena, como pedían por haber andado poco cautos los primeros Españoles, que les hablaron en ofrecerles aquel sitio, y por consiguiente se resolvió fundar allí Presidio, como se ejecutó y adelante se dirá. 
51 -372- Tomada esta resolución, por no faltarles cosa por donde pudieran sospechar engaño, mandó el Gobernador se les admitiese la paz, que ofrecían con asistencia de los Capellanes del Ejército, y de los Oficiales mayores de guerra, dando a entender al Cacique principal, y a los demás Caciques menores, y Capitanes Malbalaes por medio del intérprete las condiciones debajo de que son admitidos a la paz, y alianza con el Español, y las calidades con que se les concedía el sitio en el río de Esteco, o Valbuena, que es lo mismo, con todo lo demás, que debían en adelante observar. Y para que les sirviese de muestras de mayor confianza y de la firmeza que había de haber de parte del Español en lo que se les ofrecía, y fuesen desde luego honrados en nombre de su Majestad Católica, se determinó entregar algunas insignias al Cacique Jonastete principal Gobernador de su Nación, que distinguiesen su dignidad, y a los demás Caciques y Capitanes las que les correspondiesen, dándoles fuera de estos algunos vestidos en la forma que diese lugar la coyuntura presente interin que llegaba tiempo de poderlos vestir a todos fenecida la campaña. Y al intérprete Antonio por la fidelidad y verdad con que procedió siempre, por el amor que mostró y con que favoreció a los Españoles, y por ser entre ellos de particular estimación, como cuñado de Jonastete se le acordó dar el bastón de Sargento Mayor de su Nación, como todo se ejecutó.

Las capitulaciones pues que se hicieron fueron las siguientes. Primera, que respecto a haber sido esta Nación la primera que daba la paz entregándose con tan segura confianza al Ejército Español, mediante los buenos consejos de su Paisano Antonio, que con verdad les aseguró el buen tratamiento que hallarían todos en los Cristianos, se les perdonaban todos los atrocísimos delitos que habían cometido desde mucho tiempo antes acompañándose con las Naciones de Mocovíes, Tobas y Aguilotes. Segunda, que no obstante, que por tales atrocidades eran merecedores de que continuase guerra contra ellos con el rigor que habían experimentado, demás de perdonarles, se les admitía a la paz, amistad y alianza con la Nación Española. Tercera, que habiendo de salir del Chaco, les señalaba por ahora -373- el sitio de Valbuena, para formar su Pueblo; quedando al cuidado del Gobernador disponer lo que fuese mas de su conveniencia, a que atendería con todo amor, y empeño. 4. Que a todos los Caciques se les habían de conservar sus dignidades, nombrando el Gobernador a Jonastete en nombre de su Majestad Católica por Cacique principal de su Nación y Corregidor de su Pueblo, como le nombro luego entregándole el bastón. 5. Que al indio Antonio llamado entre los suyos Ays, por la fidelidad con que ha procedido a beneficio de ambas Naciones, Española y Malbala, siendo el faraute y principal instrumento de esta pacificación, se le había de hacer Sargento Mayor del dicho Pueblo en nombre de Su Majestad, gracia que también le acordó luego el Gobernador, entregándole el bastón. 6. Que el Gobernador hubiese de darles personas que les instruyesen en la labor de los campos y en la fábrica de sus casas y proveerles del bastimento necesario hasta recoger la primera cosecha. 7. Que los Españoles ayudarán a la Nación Malbala como buenos amigos, y aliados en todas las ocasiones que cualquiera otra Nación les hiciesen guerra sin permitir que les hagan agravio ni daño alguno, defendiéndolos contra sus enemigos. 8. Que si recibieren algún agravio de algún Español o indio Cristiano, avisando al Cabo de los Españoles, este estará obligado a darle el castigo que mereciere el delincuente; y en caso que el Cabo no les haga justicia, avisarán al Gobernador, quien castigará al delincuente por su delito, y al Cabo por su omisión; todo esto se les ofreció de parte de los Españoles, obligándose en correspondencia los Malbalaes a observar inviolablemente los Capítulos siguientes: 1. Que serían leales vasallos del Rey nuestro señor, y como tales obedecerles fielmente al Gobernador que era 
o fuese en delante de la Provincia del Tucumán. Y a todos sus Ministros, y mucho más a los mandatos de la Real Audiencia del distrito, Virrey de estos Reinos. 2. Que mantendrán perpetuamente paz y alianza con los Españoles, siendo amigos de sus amigos y enemigos de sus enemigos. 3. Que en consecuencia de esta alianza, no tendrían comunicación con los Malbalaes, Tobas, y Aguilotes ni con las demás Naciones del Chaco, o fuera de él, que son y en adelante fueren -374- enemigas del Español. 4. Que siempre que se ofreciese hacer guerra a dichos enemigos, habían de auxiliar y favorecer a los Españoles, y obedecer a su Cabo en lo que les mandare. 5. Que si recibieren agravio de algún Español o Indio Cristiano, no cogerían las armas contra él o contra ellos, sino que se querellarían al Cabo del Presidio para que les haga justicia, o al Gobernador de la Provincia, en caso que el Cabo fuese omiso. 7. Que saldrían luego de aquel contorno a poblarse en el sitio de Valbuena, que por entonces les señalaba el Gobernador. 8. Que irían desde el Río Grande hasta Valbuena sujetos y obedientes al Cabo de los Españoles que los condujese, haciendo lo que les mandase, así en el camino como en el sitio referido. 9. Que habían de admitir en su población los Predicadores Evangélicos, para que les enseñasen la Santa Ley de Dios, reverenciando y respetando a los Misioneros con todo rendimiento y asimismo al catecismo. 10. Que obedecerían al Cabo del Presidio Español, a quien darían cuenta de todo lo que ocurriese de algún momento y puntual aviso si algún Indio de los suyos se huyese o ausentase para que fuese buscado. 11. Que darían cuenta al mismo Cabo con toda puntualidad de las noticias que tuviesen de los enemigos, o lo que entendiesen de sus designios, sin consentir se acercasen a nuestras Fronteras. 12. Que los Caciques de la Nación y Capitanes atenderán vigilantes a mantener juntas en su Pueblo a todas las familias de su Nación, y a conservarlas en la amistad y alianza de los Españoles. Asentóse la paz debajo de estas condiciones, que cada una cláusula por cláusula se les fue dando a entender por medio del Interprete a los Caciques y Capitanes Malbalaes, que se ratificaron de nuevo en la promesa de cumplirlas todas puntualmente, cuanto estuviese de su parte, expresando que esperaban harían lo mismo de su parte los Españoles, y en señal del vasallaje que ofrecían al Rey nuestro señor llegó Jonastete y ofreció su dardo al Gobernador, que en fe de ello le aceptó con demostraciones de agrado. Agasajándolos mucho, regalólos con vestidos según su calidad y exhortándoles al cumplimiento de lo pactado, los despidió gustosos y contentos, para que se recogiesen a su alojamiento y su Señoría con toda su comitiva, se volvió -375- a su Fuerte de San Ignacio, aquel mismo día primero de septiembre, no menos gozoso de ver pacificada la belicosa Nación Malbalá, a quien por aquel medio esperaba se le habían de franquear las puertas de la Iglesia Católica, disponiéndose a recibir el Santo Bautismo. El gozo de los demás Españoles fue igual, fundado en las mismas piadosas prácticas.

\section{BIBLIOGRAFÍA}

Argouse, A. (2012). Testamentos de indígenas ¿Una fuente excepcional? La “voz del pueblo” y el escribano. Cajamarca, Perú, siglo XVII. Temas Americanistas, 29, 200-221. 
Bareiro Saguier, R. y Duviols, J. P. (1991). Tentación de la Utopía. En R. Bareiro Saguier y J. P. Duviols (Eds.), Tentación de la Utopía. La República de los jesuitas en el Paraguay. Barcelona: Tusquets.

Cardiel, J. ([1771] 1994). Breve relación de las misiones del Paraguay [estudio preliminar de Ernesto J. A. Maeder]. Buenos Aires: Secretaría de Cultura de la Nación / Ediciones Theoría.

Clark, Ch. U. (1937). Jesuit Letters to Hervás on american languages and customs. Journal de la Société des Américanistes, 29-1, 97-145.

Colom González, F. (2003). La imaginación nacional en América Latina. Historia Mexicana, LIII (2), 313-339.

Foucault, M. (1968). Las palabras y las cosas. Madrid: Siglo XXI.

Furlong, G. (1939). Entre los vilelas de Salta. Buenos Aires: Academia Literaria del Plata.

Gruzinski, S. (1991). La colonización de lo imaginario. Sociedades indígenas y occidentalización en el México español. Siglos XVI-XVII. México: FCE.

Lander, E. (2010). Ciencias sociales: saberes coloniales y eurocéntricos. En E. Lander (Comp.), La colonialidad del saber: eurocentrismo y ciencias sociales. Perspectivas latinoamericanas. (pp. 11-40). Buenos Aires: CLACSO.

Lozano, P. (1733). Descripción Corográfica del Gran Chaco Gualamba. Córdoba [España]: Colegio de la Asunción.

Mignolo, W. (1995). The Darker Side of the Renaissance. Literacy, Territoriality and Colonization. Ann A rbor: Michigan University Press.

Neumann, E. (2008). Escribiendo en la frontera del Paraguay. Prácticas de la escritura guaraní durante la demarcación de límites (siglo XVIII). Cultura escrita y sociedad, 7, 159-190.

Pratt, M. L. (2011). Ojos imperiales. Literatura de viajes y transculturación. Buenos Aires: FCE.

Paucke, F. (1942-44), Hacia allá y para acá. Una estada entre los indios mocovies (1743-1767), Vol. III, $2^{\mathrm{a}}$ Parte. Tucumán / Buenos Aires: Universidad Nacional de Tucumán / Institución Cultural Argentino-Germana.

Roa Bastos, A. (1991). Entre lo temporal y lo eterno. En R. Bareiro Saguier y J. P. Duviols (Eds.), Tentación de la Utopía. La República de los jesuitas en el Paraguay. (pp. 9-38). Barcelona: Tusquets.

Vitar, B. (1995). "Mansos y salvajes". Imágenes chaqueñas en el discurso colonial. En F. del Pino y C. Lázaro (Coord.), Visión de los Otros y visión de sí mismos entre España y América. (pp. 107-126). Madrid: CSIC.

Vitar, B. (1997). Guerra y misiones en la frontera chaqueña del Tucumán (1700-1767). Madrid: CSIC.

Vitar, B. (2004). Mujeres, jesuitas y poder. El caso de las reducciones de las fronteras del Chaco (siglo XVIII). Memoria Americana, 12, 39-70.

Wilde, G. (2009). Religión y poder en las misiones de guaraníes. Buenos Aires: SB. Serie Historia Americana.

Wilde, G. (2010). Entre la duplicidad y el mestizaje: prácticas sonoras en las misiones jesuíticas de Sudamérica. En A. Recasens Barberà y Ch. Spencer Espinosa (Coord.), A tres bandas. Mestizaje, sincretismo e hibridación en el espacio sonoro iberoamericano. (pp. 103-112). [Antioquia: Museo de Antioquia].

Wilde, G. (2013). Introducción [Al Dossier] "Fuentes indígenas" en la Sudamérica colonial y republicana: escritura, poder y memoria. Parte I. Corpus - Archivos virtuales de la alteridad americana, 3 (1). Disponible en http://corpusarchivos.revues.org/190 


\section{NOTAS}

1. La abundante producción etnográfica de la Compañía de Jesús ha arrojado testimonios valiosos sobre el mestizaje cultural en las misiones guaraníes, valgan como ejemplos la descripción de la fiesta del Corpus en Cardiel ([1771] 1994) o el claro sincretismo producido en el ámbito de la expresión musical que reflejan algunos elementos iconográficos en las iglesias jesuíticas (Wilde, 2010).

2. De aquí en adelante utilizo esta forma abreviada del título para referirme a la obra de Lozano.

3. Ya señalaba Foucault ese "privilegio" de lo escrito que dominó en el Renacimiento gracias a una serie de acontecimientos (entre otros, la imprenta, la "llegada" de los manuscritos orientales, el surgimiento de una literatura que "ya no era para la voz o la representación") que llevaron a la escritura a ocupar "un lugar fundamental" en la cultura de Occidente (Foucault 1968, p. 46).

4. A propósito de este asalto a la alteridad, Bareiro Saguier y Duviols (1991, p. 45) destacan que las voces de los idiomas indígenas y sobre todo las de contenido religioso, perdieron su sentido cultural original en el proceso de "resemantización" sufrido a través de la elaboración de diccionarios, gramáticas y catecismos, forzando su adecuación a los principios doctrinarios del cristianismo.

5. Sin embargo, en ciertas respuestas nativas a los dictados "racionales" del orden reduccional como el ejercicio de labores agrícolas-, subyace la lógica propia de sus modos de subsistencia Es muy ilustrativa al respecto la respuesta que un cacique mocoví de la reducción San Javier dio al misionero, tras este aconsejarle el cultivo de algodón para el beneficio comunitario: la negativa del jefe indígena había sido rotunda, bajo el argumento de que "no se puede comer el algodón" (Paucke 1943-44, Vol. III, 2 ${ }^{\text {a }}$ Parte, p. 222).

6. Lozano, 1733, p. 370.

7. La Descripción Corográfica del Gran Chaco Gualamba de Lozano se publicó por primera vez en Córdoba (España), en 1733, siendo la edición utilizada en estas notas. Su versión digitalizada se halla disponible en la Biblioteca de Humanidades (Fondo Antiguo) de la Universidad de Sevilla.

8. El inicio de la campaña contra las "naciones enemigas" del Chaco tuvo lugar el 25 de mayo de 1710 (Lozano, 1733, p. 345). Con relación al grupo malbalá, la rendición del cacique (manifestada verbalmente) se concretó a mediados de agosto de 1710, celebrándose días después las capitulaciones.

9. Otras acciones militares posteriores (entrada de 1711), también al mando del gobernador Urízar, abrieron paso a una efectiva labor jesuítica en las fronteras del Tucumán, con la fundación de la misión lule de Miraflores (1714) en las márgenes del río Salado (o Pasaje), en jurisdicción de Salta.

10. Sin obviar la importancia de la información referida a los mocovíes, en estas notas me centraré en el caso malbalá.

11. Con este grupo, asentado en la periferia noroccidental chaqueña (a orillas del río Bermejo), no se fundó una misión sino tardíamente (San José, 1753), caracterizándose por su inestabilidad debido a las fugas de los reducidos y a los sucesivos traslados del establecimiento. Un nuevo pueblo se formó en 1768, ya concluido el periodo jesuítico (Vitar 1997, pp. 294-295). Otra reducción fronteriza fue Concepción (jurisdicción de Santiago del Estero), erigida en 1743 con indígenas del grupo abipón (Vitar 1997, pp. 250-251).

12. Es el término que utiliza Lozano para referirse a las tierras que ocupaba entonces esta "parcialidad" de los malbalaes.

13. En ocasión de colaborar con Lorenzo Hervás y Panduro (autor del Catálogo de las lenguas de las naciones conocidas, publicado entre 1800 y 1805), Camaño, un gran estudioso de las idiomas indígenas, le informaba que la lengua de los malbalaes “[...] está también olvidada; aún de ellos 
mismos, porque los 15 a 20 familias que han quedado, tienen el carácter, o fortuna de los Indios, que andar dispersas, unas entre Mocovíes, otras entre Vilelas, otras entre Mataguayos, etc." (en Clark, 1937, p. 113).

14. Según Lozano, el propio intérprete (un malbalá) que guió a los españoles en la entrada de 1710 había señalado que las "chacras o sementeras" encontradas por el ejército en las riberas del río Grande o Bermejo, eran de sus "parientes” (Lozano, 1733, p. 360).

15. Conforme a los datos aportados por el gobernador Urízar en un informe al rey, fechado en Salta el 24 de julio de 1713, la "parcialidad" malbalá que se redujo en Balbuena (jurisdicción salteña) estaba formada por "seiscientas personas de todo sexo y edades" (Vitar, 1997, p. 187).

16. Archivo General de Indias (AGI), Charcas 284. Informe de Esteban de Urízar al rey sobre la campaña al Chaco. Salta, 24 de julio de 1713.

17. AGI, Informe de Esteban de Urízar...

18. AGI, Informe de Esteban de Urízar...

19. Ello se colige de la detallada descripción de la campaña al Chaco de 1710 , en la que no faltan elogios a la figura de Urízar, como buen militar y caballero "piadoso". Al respecto, cabe señalar que este gobernador favoreció la acción evangelizadora de Compañía de Jesús en las fronteras del Tucumán, mediante la adjudicación de mercedes de tierras para la fundación de las primeras reducciones del río Salado, en jurisdicción de Salta (Vitar 1995, p. 115-117).

20. Los grupos toquistinés, oristinés e isistinés (considerados como "parcialidades" de los lules) y los llamados "propiamente" lules fueron congregados definitivamente en la misión de Miraflores en 1714, tras un previo alojamiento en el presidio de Balbuena (Vitar 1997, p. 233).

21. Junto a la complejidad del panorama lingüístico, en el que resalta la consolidación del quechua como lengua franca, habría que marcar la heterogeneidad de las fuerzas que componían el ejército colonial, formado no sólo por españoles, "sino también [por] Indios amigos y mulatos libres, que en las Indias suelen llamar pardos” (Lozano, 1733: 343).

22. En quechua: alto dignatario, jefe del ejército, entre otras acepciones (Jacobs, Philip (COMP.). AULEX, Diccionario quechua - español Runasimi en línea. Disponible en: http://runasimi.de; http://aulex.org/qu-es/?busca=apu). [Consulta 10/07/2013].

23. Por lo general, los intérpretes eran reclutados entre indígenas prisioneros de las fuerzas coloniales, siendo con posterioridad adiestrados al efecto.

24. El gobernador Urízar informaba al rey en similares términos, indicando que se trataba de un indio "principal" y cuñado del cacique, "apresado dos años antes en la frontera de la Ciudad de Tucumán, adonde vino con sus soldados a ejecutar sus invasiones; y habiendo conocido que era caudillo, mandé llevarlo a Buenos Aires, donde aprendiese la lengua española, sin riesgo de volverse a sus tierras, encargando su buen tratamiento y que se procurase introducir en [su] ánimo amor firme al español a fin de traerlo por intérprete y guía en el dilatado espacio que contienen las provincias del Chaco, habitadas de muchas bárbaras naciones" (Informe de Esteban de Urízar... 24 de julio de 1713, documento citado. El resaltado me pertenece.).

25. No es sino en este punto del relato donde Lozano desvela la condición de jefe del padre del lenguaraz.

26. La comunicación verbal de su rendición fue hecha por Jonastete a mediados de agosto de 1710: "Por fin se llegó al día feliz, en que se entregó la principal parcialidad de la Nación Malbalá, que fue Sábado 16 de Agosto" (Lozano, 1733, p. 367). Las capitulaciones se celebraron el 27 de ese mismo mes (pp. 368, 371-372).

27. Así lo destaca la fuente (v. Lozano, 1733, p. 361).

28. Lozano, 1733, p. 369.

29. También, el hecho de rubricar un acto de rendición de modo escrito, nos acerca a las prácticas notariales introducidas en el mundo indígena, v. gr. los testamentos hechos por estos, dictados al escribano por un intérprete al tener que registrarse en lengua española, como indica Argouse (2012, p. 210) con relación al ámbito colonial peruano. 
30. Cabe subrayar que en este pasaje de la narración, referido a los primeros encuentros con los malbalaes, Lozano no presenta al padre del lenguaraz con su nombre ni tampoco con la indicación de su rango de "capitán"; en cambio, sí ofrece estos detalles al describir el momento de las capitulaciones (Lozano 1733, pp. 362, 369).

31. La ortografía original ha sido modernizada con el fin de una lectura más ágil. Todas las palabras en cursiva que aparecen en esta transcripción figuran en la edición original utilizada para este artículo. Se mantiene también el uso de mayúsculas y minúsculas según los usos variables del autor con relación a algunos términos, en los que se alternan uno y otro tipo de letra.

32. Así figura el título del Parágrafo en la edición original. Río Grande era el nombre que se daba también al Bermejo, en cuyas cercanías vivían los malbalaes.

33. En adelante, sólo se consignará en negrita el número de cada página, para facilitar su localización. La numeración indicada en esta transcripción corresponde a la de la edición original.

34. Ciudad situada al este de la jurisdicción de Salta, fundada a orillas del río Pasaje (nombre que adopta en la zona el río Salado), destruida en 1692 por un terremoto. Sobre sus ruinas se fundó el presidio del Rosario o de Esteco, con el propósito de resguardar parte de la frontera salteña.

35. Batalla librada el 20 de agosto de 1710 (Guerra de Sucesión Española).

36. En cobro: a salvo.

37. Año de 1710.

38. Ansioso, acelerado. (DRAE).

39. Gabán rústico de paño burdo y sin mangas, que se pone sobre las demás prendas para protegerse del frío y de la lluvia. (DRAE).

40. Junto al de Fuerte del Rosario, los nombres que señalo entre corchetes son indistintamente utilizados por Lozano para aludir a dicha fortificación, construida en el sitio en que se fundó la antigua ciudad de Esteco.

41. Río Grande (fronteras de Jujuy, dentro de la jurisdicción de la provincia del Tucumán). Este río, al ingresar en Salta toma el nombre de San Francisco, donde une su afluente al del río Bermejo.

\section{RESÚMENES}

A través del análisis de un fragmento de la crónica de Pedro Lozano, referida a la campaña del ejército colonial en las fronteras del Chaco en 1710, se trata de reflexionar sobre la producción de una fuente "indígena" en un contexto de guerra e interacciones fronterizas. El relato de Lozano sobre las capitulaciones celebradas entre los malbalaes y las huestes coloniales, reproduce una breve frase, escrita por el "cacique" del grupo, por la que este anunciaba su oferta de paz. A lo largo de estas notas, introducimos varios planteamientos que nos llevan a adelantar una primera conclusión: el carácter singular de la fuente, en la que se mezclan tradiciones hispánicas y la agencia indígena. En este sentido, el escrito del cacique puede ser considerado como resultado de los intercambios hispano-indígenas en las fronteras.

Through the analysis of a fragment of Pedro Lozano' chronicle, dealing with the campaign of the colonial army on the Chaco's border in 1710, we try to think about the production of a "indigenous" source in a context of war and borders contacts. Lozano's narrative on the 
capitulations celebrated between the malbalaes and the colonial forces, reproduces a brief phrase written by the cacique of the group, for which this one announced his offer of peace. Along these following notes, we expose several considerations that lead us to advancing the first conclusion: the singular character of the source, in which mixed Hispanic traditions and indigenous agency. In this sense, the writing of the cacique may be considered as the result of the Hispanicindigenous interactions on the boundaries.

ÍNDICE

Keywords: Frontiers, jesuit chronicles, indigenous writing

Palabras claves: Fronteras, crónicas jesuíticas, escritura indígena

\section{AUTOR}

BEATRIZ VITAR

Universidad de Sevilla, España

Correo electrónico: mvitar@us.es 